\title{
Cell-Biological Requirements for the Generation of Dentate Gyrus Granule Neurons
}

\author{
Maryam Hatami ${ }^{1}$, Sabine Conrad ${ }^{2}$, Pooyan Naghsh ${ }^{3}$, Gonzalo Alvarez-Bolado ${ }^{1}$ and \\ Thomas Skutella ${ }^{1 *}$
}

${ }^{1}$ Institute for Anatomy and Cell Biology, Heidelberg University, Heidelberg, Germany, ${ }^{2}$ Independent Researcher, Tübingen, Germany, ${ }^{3}$ Department of Biochemistry and Molecular Biology, University of Calgary, Calgary, AB, Canada

\section{OPEN ACCESS}

Edited by:

Josef Bischofberger,

Universität Basel, Switzerland

Reviewed by:

Shaoyu Ge

Stony Brook University, United States

Ashwin S. Shetty,

Harvard University, United States

*Correspondence:

Thomas Skutella

skutella@ana.uni-heidelberg.de

Received: 09 August 2018

Accepted: 18 October 2018

Published: 12 November 2018

Citation:

Hatami M, Conrad S, Naghsh P, Alvarez-Bolado G and Skutella T (2018) Cell-Biological Requirements for the Generation of Dentate Gyrus

Granule Neurons.

Front. Cell. Neurosci. 12:402.

doi: 10.3389/fncel.2018.00402
The dentate gyrus (DG) receives highly processed information from the associative cortices functionally integrated in the trisynaptic hippocampal circuit, which contributes to the formation of new episodic memories and the spontaneous exploration of novel environments. Remarkably, the $D G$ is the only brain region currently known to have high rates of neurogenesis in adults (Andersen et al., 1966, 1971). The DG is involved in several neurodegenerative disorders, including clinical dementia, schizophrenia, depression, bipolar disorder and temporal lobe epilepsy. The principal neurons of the $D G$ are the granule cells. DG granule cells generated in culture would be an ideal model to investigate their normal development and the causes of the pathologies in which they are involved and as well as possible therapies. Essential to establish such in vitro models is the precise definition of the most important cell-biological requirements for the differentiation of DG granule cells. This requires a deeper understanding of the precise molecular and functional attributes of the DG granule cells in vivo as well as the DG cells derived in vitro. In this review we outline the neuroanatomical, molecular and

Abbreviations: 1stM, First Matrix; 2ndM, Second Matrix; 3rdM, Third Matrix; Acvr1, activin receptor type 1 (gene); Apc, adenomatosis polyposis coli (gene); Apcdd1, APC down-regulated 1 (gene); Ascl1, achaete-scute family bHLH transcription factor 1 (gene); Bdnf, brain-derived neurotrophic factor (gene); Bmprla, bone morphogenetic protein receptor la (gene); BMPs, bone morphogenetic proteins; CA, Ammon's horn (Cornu Ammonis) of the hippocampus; Calb1, calbindin 1 (gene); CcnD2, cyclinD2; CDKs, cyclin-dependent kinases; $\mathrm{CH}$, cortical hem; ChP, Choroid Plexus; CNS, central nervous system; CP, Choroid Plaque; CR, Cajal-Retzius cells; Cxcr4, chemokine receptor type 4; DG, dentate gyrus; Dkk, Dickkopf-related protein; DNE, Dentate Neuroepitelium; EB, embryoid body; Egf, epidermal growth factor (gene); Emx1, empty spiracles homebox 1 (gene); Emx2, empty spiracles homebox 2 (gene); F, fimbria; FGF, fibroblast growth factor; Foxg1, forkhead box G1 (gene); GABA, gamma-aminobutyric acid; GDFs, growth and differentiation factors; GDPs, giant depolarizing potentials; GFs, growth factors; Gli3, Glioma-Associated Oncogene Family Zinc Finger 3 (gene); GRIK4, glutamate receptor, ionotropic, kainate 4 (human gene); KA1; G $\Omega$, giga Ohms; Hes5, hairy and enhancer of split 5 (gene); HF, hippocampal fissure; HNE, Hippocampus Neuroepithelium; hPSC, human PSCs; Id, inhibitor of DNA binding; IPCs, intermediate precursor cells; iPSCs, induced PSCs; KA1, GRIK4 (gene); LacZ, $\beta$-galactosidase; Lef1, lymphoid enhancer binding factor 1; Lhx5, LIM homeobox protein 5; Lrp6, lipoprotein receptor-related protein 6; MS, Migratory Stream; $\mathrm{mV}$, millivolts; NeuN, "Neuronal Nuclei", neuron-specific nuclear antigen, mouse nuclear protein Rbfox3, RNA binding protein, fox-1 homolog (C. elegans; specific neuronal marker); NeuroD1, neuronal differentiation 1 (gene); Neurog2, neurogenin 2 (gene); Nfix, nuclear factor I/X (gene); Nr2e1, nuclear receptor subfamily 2, group E, member 1 (gene); NSCs, neural stem cell; Pax6, paired box 6 (gene); pF, picofarad; Prox1, prospero homeobox 1 (gene); PSCs, pluripotent stem cells; Ptch1, receptor patched 1 (gene); Rin, input resistance; Rspo, R-spondins (gene); Sdf1, stromal cell-derived factor 1 (gene); Sfrp2, secreted frizzled-related protein 2 (gene); Shh, sonic hedgehog (gene); Smo, smoothened (gene); Tbr2, T-box brain protein 2 (gene); TCF/LEF, transcription factor/lymphoid enhancer binding factor, a family of transcription factors in the Wnt pathway; TF, transcription factor; TGFB, transforming growth factor beta, signaling protein with four isoforms (1-4); TGFB1, transforming growth factor beta 1 (gene); Vm, membrane resting potential of a neuron; VZ, ventricular zone; WNT, Wnt signaling pathway; ZBTB20, Zinc finger and BTB domain-containing protein 20 (gene). 
cell-biological components of the granule cell differentiation pathway, including some growth- and transcription factors essential for their development. We summarize the functional characteristics of DG granule neurons, including the electrophysiological features of immature and mature granule cells and the axonal pathfinding characteristics of DG neurons. Additionally, we discuss landmark studies on the generation of dorsal telencephalic precursors from pluripotent stem cells (PSCs) as well as DG neuron differentiation in culture. Finally, we provide an outlook and comment critical aspects.

Keywords: dentate gyrus, granule cells, induced pluripotent stem cells (iPSC), in vitro, requirements

\section{DEVELOPMENT OF THE DENTATE GYRUS (DG) AT THE HISTOLOGICAL LEVEL (FIGURE 1)}

Before thinking of producing dentate gyrus (DG) granule cells (or the entire DG itself) in vitro, it is convenient to review the formation of the DG in the mouse brain at the histological level. Key structures for DG development are: (1) the cortical hem $(\mathrm{CH})$ and the anti-hem; (2) the radial glia; (3) the Cajal-Retzius cells (CR); and (4) the surrounding meninges. DG development is regulated by growth factor gradients which in turn activate transcription factor expression in the corresponding precursor cells and in the differentiating neurons. The DG originates in three proliferative matrices and the cellular events leading to its formation can be best described as subdivided into three developmental stages.

\section{First Stage}

DG development begins with the expansion of the undifferentiated neuroepithelium sheet (ventricular zone, VZ) of the early cortical primordium. During this phase, signal morphogens are secreted from two discrete telencephalic regions: the $\mathrm{CH}$, a long and narrow region caudal and adjacent to the presumptive hippocampal neuroepithelium, and the more rostrally located anti-hem. The $\mathrm{CH}$ is considered one of the organizers (or patterning centers Rubenstein and Beachy, 1998; Grove and Fukuchi-Shimogori, 2003). The morphogens provide positional cues and regulate the regional proliferation and architecture in the developing cortex. The cortical neuroepithelium responds to these signals by generating a cortical proto-map (Grove and FukuchiShimogori, 2003) through region-specific neurogenesis and gliogenesis. The first subset of proliferative neuroepithelial cells of the DG (i.e., the first proliferative matrix or the DG presumptive neuroepithelium) is regionalized as part of the medial pallium VZ.

\section{Second Stage}

DG progenitors go on dividing by mitosis as they leave the VZ and migrate towards the hippocampal fissure (HF); these migrating precursors constitute the secondary proliferative matrix. This is a unique phenomenon: a migrating population of mitotically active progenitors at various differentiation stages. The migration is guided by a radial glial scaffold, which originates from the fimbrial region and leads to the pial side of the cortex and the HF. Additionally, a special kind of neurons, the CR cells, originating in the $\mathrm{CH}$ and migrating towards the HF, provide factors essential for DG precursor migration (Rickmann et al., 1987; Del Río et al., 1997). CR cells express reelin (Reln), which encodes a protein essential for the migration of neurons along radial glia. The formation of the radial glial scaffold is triggered by a cascade of interactions involving Reln, Disabled1 (Dab) and Integrin betal (Itbg1; Förster et al., 2002). In mice deficient in Reln, the cell-dense DG granule layer, precisely demarcated from the hilus (Förster et al., 2002), fails to form, and the granule cells are misplaced in the hilus area (Förster et al., 2002).

\section{Third Stage}

Upon arrival to the HF, the DG migrating progenitors (secondary proliferative matrix) accumulate in this region and form the tertiary proliferative matrix. Granule cells originate in all three matrices. CR cells surrounding the HF and the pial surface define the granule cell layer (GCL)'s well-known V-shaped progenitor and granule cells become gradually limited to the tertiary matrix. In the early postnatal phase, the subgranular zone (i.e., the presumptive adult hippocampal neurogenesis site) develops from the tertiary matrix (Bayer, 1980a,b; Altman and Bayer, 1990; Pleasure et al., 2000; Brunne et al., 2010; Khalaf-Nazzal and Francis, 2013; Sugiyama et al., 2013).

Let us mention here briefly the development of axonal connections, a complex subject in itself, which has been often reviewed in this context (see for instance Skutella and Nitsch, 2001). During development, the formation of hippocampal connections is directed by a complex guidance signaling network. The developing hippocampus originates outgrowing axons which navigate using long-range cues including secreted class3 Semaphorins, Netrin1 and Slit proteins. Layer-specific positional information is communicated by regional molecules in the membrane or anchored in substrates like ligands of the Ephrin A subclass. In the adult mouse DG, the silencing of semaphorin receptors neuropilins1 or 2 in neural progenitors in vivo causes newly differentiated neurons with shorter dendrites and simpler branching ( $\mathrm{Xu}$ C. J. et al., 2015).

\section{FUNCTIONAL INTEGRATION OF NEWBORN DG GRANULE CELLS}

Although in the mouse the first DG granule cells are generated during the final phase of embryogenesis, most granule cell 

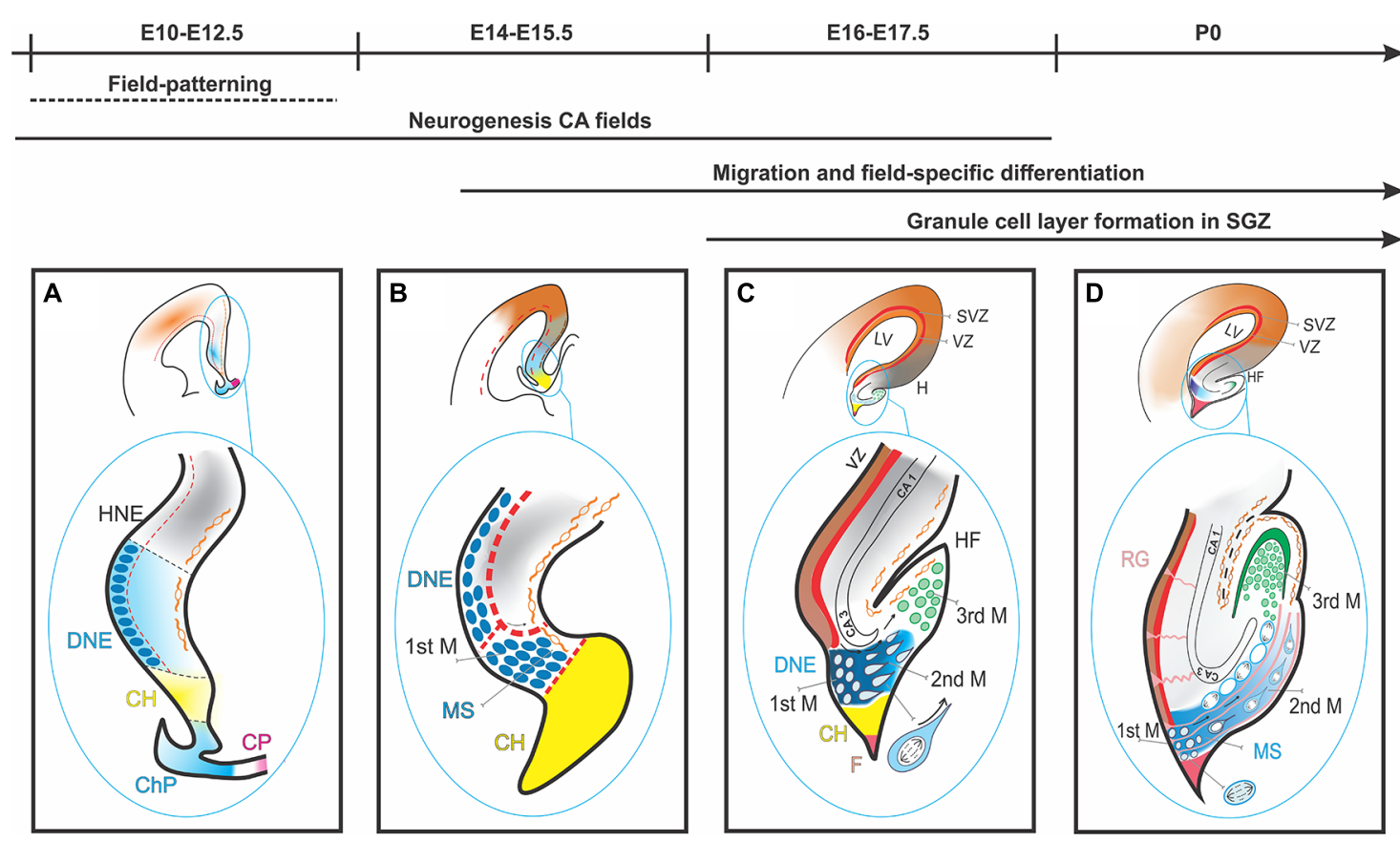

FIGURE 1 | Dentate gyrus (DG) development in the mouse from E10 to postnatal stage. (A) The migration and differentiation of granule cells is controlled by the $\mathrm{CH}$, a glial scaffold formed by radial glial cells (RGCs) and CR lining the HF. At E10-E12.5 DG precursor cells (small dark blue) start to develop in the DNE, adjacent to CH (light blue). (B) By E14-E15.5 the first migration of DG precursors is initiated. (C) By E17.5 DG precursors and granule cells have begun to mix and form the 2ndM and 3ndM. (D) By PO condensing of granule cell layers (GCLs) in subgranular zone. HNE, Hippocampus Neuroepithelium; DNE, Dentate Neuroepithelium; CH, Cortical Hem; ChP, Choroid Plexus; CP, Coroid Plaque; 1stM, First Matrix; MS, Migratory Stream; CR, Cajal Retzius; 2ndM, Second Matrix; 3ndM, Third Matrix; HF, hippocampal fissure; F, Fimbria.

neurogenesis occurs within the first two postnatal weeks. After that, the rate of granule cell production decreases significantly (about 90\% less neurons are generated in rats and humans of medium age in comparison to young animals; Schlessinger et al., 1975; McDonald and Wojtowicz, 2005; Knoth et al., 2010; Kempermann, 2011; Lopez-Rojas and Kreutz, 2016). This reduced neurogenesis correlates with the decline in cognitive capabilities that is typical of aging (Drapeau and Nora Abrous, 2008; Seib and Martin-Villalba, 2015), and it could be the cause of certain deficits in pattern separation also associated with the aging process (Sahay et al., 2011; Yassa et al., 2011; Holden and Gilbert, 2012).

The functional (electrophysiological) maturation of hippocampal neurons is probably regulated by a genomic network mostly independent from external stimuli; this would explain the fact that the sequence of events leading to the functional (electrophysiological) differentiation of hippocampal neurons is the same for neurons generated in embryonic and early postnatal brains and for neurons generated in the adult (Espósito M. S. et al., 2005). Accurate descriptions of the physiology of postnatally generated DG granule cells are available (adult neurogenesis in the DG and its functional implications have been reviewed in detail recently (Christian et al., 2014; Yu et al., 2014b; Abrous and Wojtowicz, 2015; Opendak and Gould, 2015). In the adult, DG granule cells originate from neuronal stem cells from the subgranular zone. During the 1st week of their generation, and right after commitment to the neuronal lineage, the early neuroblasts drift towards the inner granular cell layer and send out the first cellular processes. However, these neuroblasts are not fully involved in the trisynaptic network and they show electrical activity when excited by ambient $\gamma$-aminobutyric acid (GABA), not glutamate (Espósito M. S. et al., 2005). During the 2 nd week, fast growth of neurites and synaptogenesis are characteristic, as the essential integration of the DG into the synaptic network takes place. Over $50 \%$ of cells generated from adults do not integrate and undergo apoptosis (Gould et al., 1999; Dayer et al., 2003; Sierra et al., 2010). GABA triggers the first functional synaptic inputs in young granule cells. During the $3 \mathrm{rd}$ week, the new DG granule cells start to receive glutamatergic axons from the entorhinal cortex and to build the corresponding postsynaptic contacts in their dendrites (Espósito M. S. et al., 2005; Overstreet Wadiche et al., 2005). Dendritic spines start to appear in granule cells from week 2 on, and their number constantly increases until the 8th week, when it reaches its maximum. Afterwards, spines continue to mature until week 18. Spine motility undergoes dynamic changes, which are maximal in the 4 th to 8 th weeks and diminish afterwards (Zhao et al., 2006).

Early during the 2nd week, the axons of the granule cells mature and form synaptic contacts with CA3 postsynaptic targets; however, the contacts are stable only from the 4th week on (Zhao et al., 2006; Gu et al., 2012). Eight weeks after their generation, granule cells have reached their final anatomical destination and show mature function. During this phase they 
can barely be discerned from granule cells generated during embryonic and early postnatal development (Laplagne et al., 2006; Ge et al., 2007; Mongiat et al., 2009).

The functional integration of DG granule cells is also possible in culture. It has been reported that, after 3 weeks of differentiation, cultures of immature DG granule neurons on hippocampal astrocytes show functional neural networks ( $\mathrm{Yu}$ et al., 2014a). Somatic intracellular $\mathrm{Ca}^{2+}$ dynamics obtained from selected regions of these cultures reflects neuronal activity patterns of hippocampal granule cells and can be used as a proxy of spontaneous activity and functional connectivity. Furthermore, transplantation of pre-patterned hippocampal NPCs into the DG of perinatal mice gives rise to functional neurons in the GCL that are properly integrated into the hippocampal neural circuitry ( $\mathrm{Yu}$ et al., 2014a).

\section{MORPHOGENETIC PROTEINS AND GROWTH FACTORS ESSENTIAL FOR THE GENERATION OF DG GRANULE CELLS (FIGURE 2)}

In Sections "Morphogenetic Proteins and Growth Factors Essential for the Generation of DG Granule Cells (Figure 2)," to "Other Proteins Necessary for the Maintenance of DG Granule Cells in Postnatal and Adult Stages: Tlx and Ccnd2," we will outline key components of the molecular framework underlying the visible developmental stages that we just described. First, we will focus on essential secreted

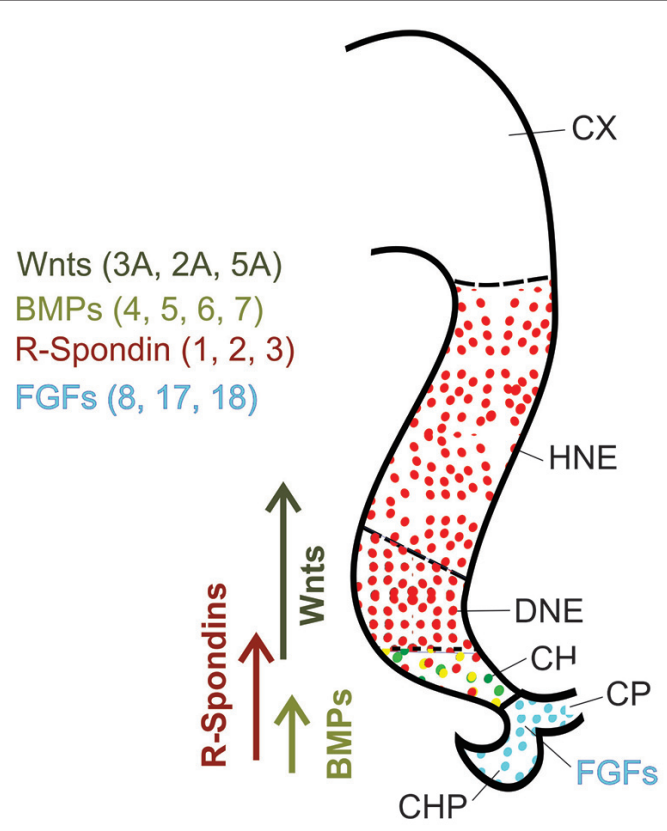

FIGURE 2 | Major secreted proteins and growth factors in hippocampal development at E11.5. WNT and bone morphogenetic protein (BMP) ligands are secreted from the $\mathrm{CH}$, while the $\mathrm{ChP}$ plexus secretes fibroblast growth factors (FGFs). R-Spondins are secreted proteins expressed not only in the $\mathrm{CH}$ but also widely in the hippocampal neuroepithelium. morphogenetic proteins indispensable for DG granule cell development. Under the influence of the signaling cascades activated by these proteins, early precursor cells will express combinations of transcription factors that we will examine in Sections "Some Transcription Factors Essential for DG Granule Cell Development (Figures 3, 4)" and "Some Transcription Factors Essential for DG Granule Cell Migration (Figure 2)."

\section{Essential Morphogenetic Proteins in DG Development}

The $\mathrm{CH}$ secretes bone morphogenetic proteins (BMPs) and WNT protein ligands (as well as growth and differentiation factors (GDFs); see Sections "Fibroblast Growth Factors (FGFs)" and "Cytokine SDF1 Secreted by Cajal-Retzius cells"). The anti-hem secretes fibroblast growth factor 7 (FGF7), epidermal growth factor (EGF) and sonic hedgehog ( $\mathrm{SHH}$ ), as well as secreted frizzled-related protein 2 (SFRP2; an inhibitor of WNT signaling; Tole et al., 1997; Grove and Tole, 1999). Furthermore, the meninges surrounding the developing DG secrete BMP7 (Choe et al., 2013). In addition, the $\mathrm{CH}$ expresses $\mathrm{R}$-spondins (Rspo), encoding secreted modulators of WNT signaling, whose functions in the DG have not been analyzed yet.

\section{WNT Ligands From the Cortical Hem}

In the mouse, hippocampus development begins around embryonic day 14 in reaction to BMP and WNT ligands secreted by the $\mathrm{CH}$ (Grove et al., 1998; Mangale et al., 2008), and disruption of this structure results in abnormal hippocampal development (Yoshida et al., 2006). The WNT ligands secreted by the $\mathrm{CH}$ (WNT2a, $-2 \mathrm{~b},-3 \mathrm{a}$ and $-5 \mathrm{a}$ ), are major players in the proliferation and organization of hippocampal neural precursors (Furuta et al., 1997; Galceran et al., 1999; Lee et al., 2000; Caronia et al., 2010). Key among them is Wnt3a, whose expression starts very early and is restricted to the $\mathrm{CH}$ (Grove et al., 1998; Lee et al., 2000). In mutant mice deficient in Wnt $3 a$, the DG is absent at the medial border of the hippocampus formation, while the CA3 and CA1 regions and the subiculum are absent rostrally and very decreased in size caudally. Deficiency in low density lipoprotein receptor-related protein 6 (Lrp6, the WNT receptor) causes severe hippocampal abnormalities (Yoshida et al., 2006). Additionally, the expression of multiple WNT modulators in the $\mathrm{CH}$ strongly suggests a requirement for tight regulation of $\mathrm{WNT} / \beta$-catenin signaling during hippocampal development (see below, Section "Gli3"). An essential transcription factor downstream Wnt signaling in this region is lymphoid enhancer binding factor 1 (LEF1; see below, Section "Lef1").

\section{BMP Ligands From the Cortical Hem}

Various BMPs, including BMP4, $-5,-6$ and -7 , are secreted by the telencephalic roof plate in an early embryonic phase, and by the $\mathrm{CH}$ in a later phase (Furuta et al., 1997; Grove et al., 1998; Hebert et al., 2002). A complete lack of BMP signaling leads to missing telencephalic medio-dorsal structures, including choroid plexus $(\mathrm{ChP})$ and $\mathrm{CH}$, which in turn results in complete lack of hippocampal development 

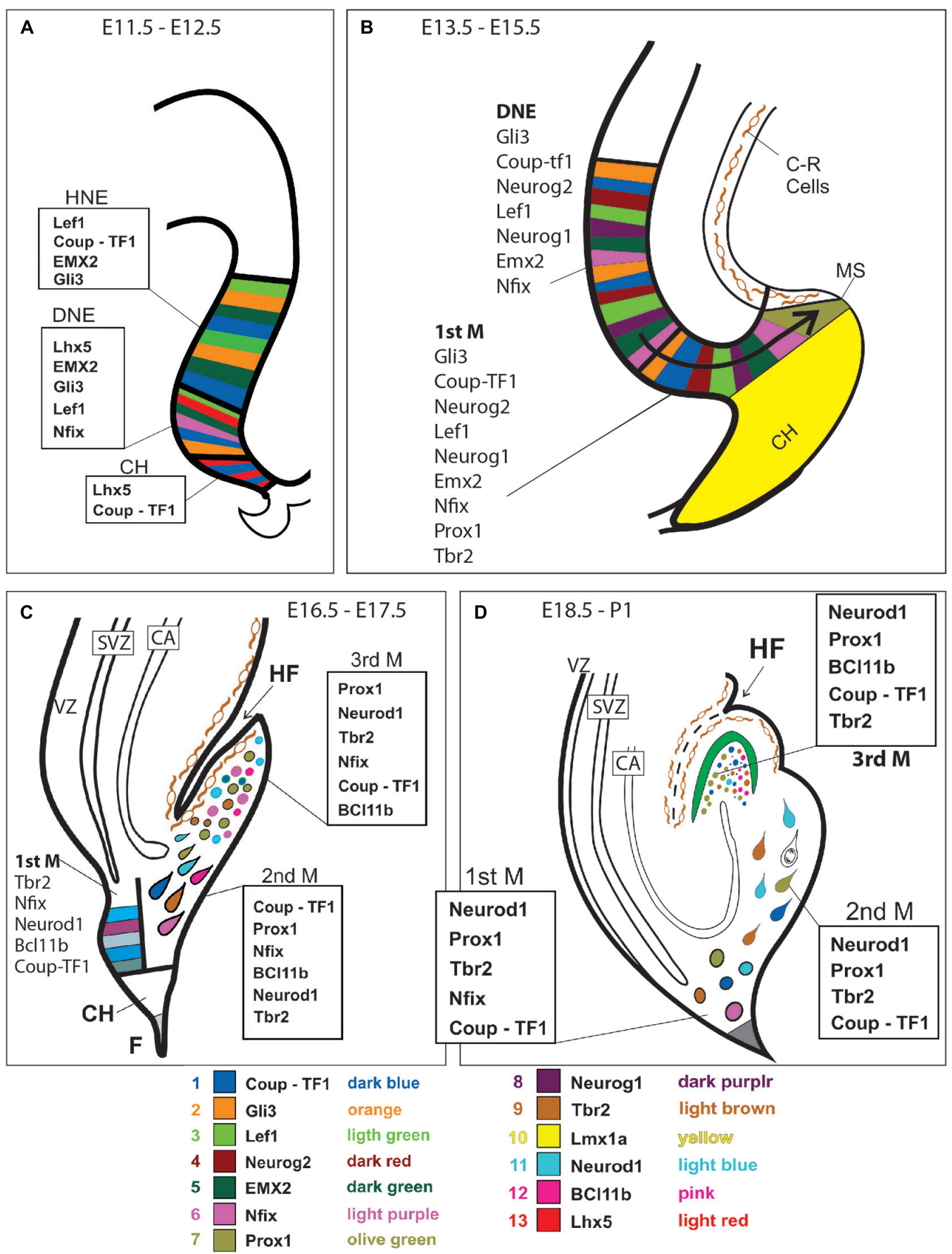

FIGURE 3 | Transcription factor expression in DG development. Expression of the most important transcription factors is represented at four different developmental ages (as indicated) and superimposed to diagrams of the corresponding histological events. Possible cellular colocalization of markers has not been represented. See text for details. Gene expression is depicted at E11.5-E12.5 (A); at E13.5-E15.5 (B); at E16.5-E17.5 (C), and at E18.5-P1 (D).

(Cheng et al., 2006; Fernandes et al., 2007). Upon formation of the $\mathrm{CH}$, BMPs seem to be no longer necessary for determining the early hippocampal cell properties (Hebert et al., 2002). Due to the differential functions of receptors BMPR-1a and BMPR-1b, BMP ligands have different effects on neural precursors: while proliferation of the embryonic telencephalon is promoted by BMPR-1a, cell cycle arrest and differentiation are supported by BMPR-1b (Panchision et al., 2001).

In addition, some properties of BMP ligands in the adult DG are of interest for researchers testing protocols for the in vitro differentiation of DG granule cells. BMPs 


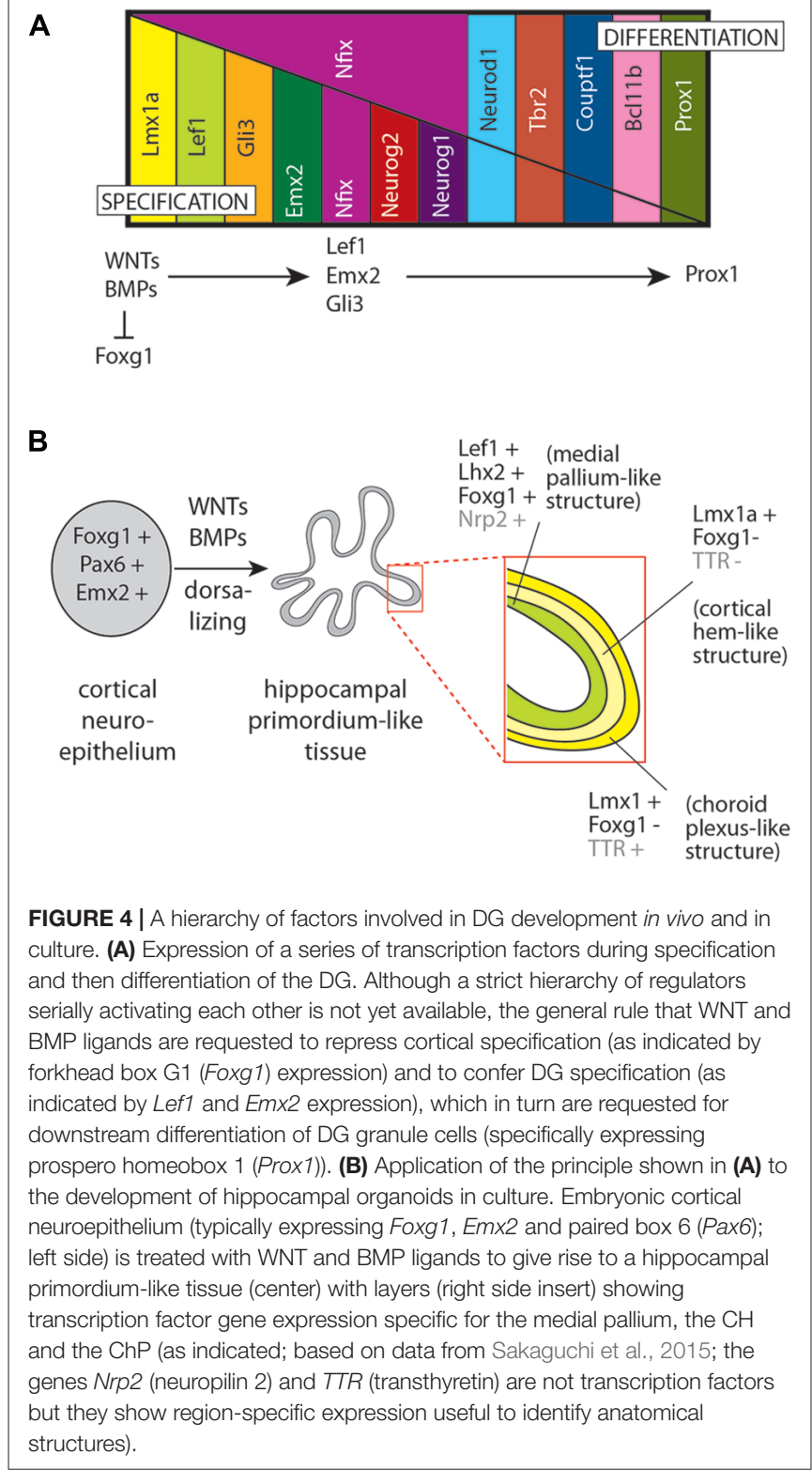

play a crucial role in maintaining neural stem cell (NSC) quiescence (Mira et al., 2010). The morphogen proteins NOGGIN and CHORDIN antagonize BMPs in the adult hippocampal proliferation niche (Scott et al., 2000; Fan et al., 2003; Bonaguidi et al., 2005, 2008). Depletion of the BMPR-1a receptor subunit results in overproduction of neurons (to the expense of proliferating NSCs) by adult NSCs and therefore reduces their population (Mira et al., 2010). BMPs can also trigger NSCs quiescence in culture (Mira et al., 2010; Sun et al., 2011; Martynoga et al., 2013) and they can support astrocytic gene expression in vitro, which again allows the induction of a selection of astroglial features of adult NSCs (Gross et al., 1996; Sun et al., 2011). The fact that BMPs are essential for the quiescence of NSCs as well as for the differentiation and maturation of granule cells (Bond et al., 2014), can be explained by the differential expression of BMPR-1 receptors. In the adult DG, NSCs express BMPR-1a, which is then downregulated in intermediate precursor cells (IPCs). Contrarily, neurons express BMPR-1b (Lim et al., 2000; Mira et al., 2010).

Finally, BMP acts through the activin receptor type 1 (ACVR1) which in turn induces Lef1 expression (Choe et al., 2013). Lef1 is a key transcription factor gene activated not only by WNT ligands but also by BMPs (Armenteros et al., 2018; see below, Section "Lef1").

\section{Sonic Hedgehog (SHH)}

Secreted morphogen protein SHH, in combination with WNT signaling, is involved in later developmental stages of the DG. It plays an important role in expanding the granule neural progenitor population during perinatal development (Machold et al., 2003). SHH and its receptor patched 1 (PTCH1) are expressed during early postnatal phases in the hilar DG regions, CA3, and along fimbria fibers (Lai et al., 2003; Machold et al., 2003). Ablation of Smoothened (Smo), encoding a component of the SHH receptor complex, leads to abnormalities in regions of postnatal neurogenesis, e.g., a reduced amount of granule DG cells compared to other hippocampal regions (Machold et al., 2003; Han et al., 2008). DG cell proliferation can also be reduced by pharmacological inhibition of SHH signaling through cyclopamine (Lai et al., 2003). In contrast, increased SHH signaling in vitro causes higher DG cell proliferation, which confirms that SHH has mitogenic effects in vivo (Lai et al., 2003; Machold et al., 2003; Han et al., 2008).

\section{Fibroblast Growth Factors (FGFs)}

Several members of the FGFs family of secreted proteins with growth and differentiation functions are expressed in the early $\mathrm{ChP}$ and elicit specific gene expression in the adjacent primordium of the hippocampus, including the DG (Zimmer et al., 2010). The gene for Fgf receptor 1 ( Fgfr 1 ), necessary for FGFs to exert their effects on the target cells is expressed in the entire hippocampus (CA and DG), from the neuronal precursors of the neuroepithelium to the postmitotic pyramidal cells and DG granule cells; mutants deficient in Fgfr 1 have 30\%-50\% less granule cells in the DG (Ohkubo et al., 2004).

\section{Cytokine SDF1 Secreted by Cajal-Retzius Cells}

We have already mentioned reelin (RELN), a protein secreted by the Cajal-Retzius neurons (see above, Section "Development of the DG at the Histological Level (Figure 1)"). The chemokine Stromal cell-derived factor 1 (SDF1, CXCL12) is a chemoattractive protein also secreted by CR cells to help DG granule precursors migrate from the neuroepithelium to the DG granule layer (Bagri et al., 2002). In mouse mutants deficient in chemokine receptor type 4 (CXCR4), the DG and the migration path contain less proliferating cells, differentiation is untimely and they have a smaller DG lacking its well-known V-shape (Lu et al., 2002). This indicates that CR cells do not directly determine granule cell development, but DG formation (cytoarchitecture). 


\section{Summary}

The interplay between WNT and BMP ligands and $\mathrm{SHH}$ establishes and sustains the DG stem cell niche (Galceran et al., 2000; Chenn and Walsh, 2002; Machold et al., 2003; Zhou et al., 2004; Lie et al., 2005; Machon et al., 2007; Favaro et al., 2009; Caronia et al., 2010; Mira et al., 2010; Munji et al., 2011). FGFs stimulate proliferation and are essential for both Ammon's horn (CA) and DG to reach the appropriate number of cells (Ohkubo et al., 2004). Therefore, for the early generation of DG granule cells in culture, it will be important to use WNT and BMP ligands for specification as well as FGFs to stimulate proliferation.

\section{SOME TRANSCRIPTION FACTORS ESSENTIAL FOR DG GRANULE CELL DEVELOPMENT (FIGURES 3, 4)}

The secreted proteins reviewed above elicit expression of transcription factor genes which further the proliferation, migration and differentiation of granule cell precursors. When trying to produce DG granule cell in vitro, the expression of these transcription factors can be used to determine if addition of BMPs, WNTs, et cetera to the culture has effected the desired results. Alternatively, forced expression of combinations of these transcription factors can be attempted in culture in order to steer the differentiation of progenitor cells.

A myriad of transcription factors are involved in the development of such a complex structure as the DG. Here we will review some particularly important, especially if their relevance to the production of DG neurons in culture has been shown. This selection has to be necessarily limited to a few really indispensable as markers of key stages in DG granule cell development.

\section{Lef1}

Among the nuclear mediators of WNT signaling are Lef1 and other genes of the TCF/LEF family of transcription factors (Galceran et al., 2000). Lef1 is highly expressed in the neuronal precursors of the DG and, less intensely in those of the adjacent (CA) region (Allen Brain Atlas; Lein et al., 2007). Lef1-deficient mouse embryos specifically lack any DG granule cells (Galceran et al., 2000). The entire hippocampal area including the CA fields is absent in mouse embryos homozygous for a Lef1lac $Z$ fusion gene encoding a protein which not only lacks DNA binding domain but impairs transcriptional activation by other LEF/TCF proteins. Consequently, the generation of DG granule cells is controlled by LEF1, which also regulates hippocampal regional development in combination with other LEF/TCF proteins.

\section{Gli3}

We have mentioned above $\mathrm{SHH}$ (Section "Morphogenetic Proteins and Growth Factors Essential for the Generation of DG Granule Cells (Figure 2)"), a secreted morphogen protein that exerts its effects through the GLI-Kruppel family of conserved zinc finger-transcriptional regulators. Dorsal telencephalon development is controlled at an early stage by Gli-Kruppel family member GLI3 (Theil et al., 1999). The brain of the extra-toesJ (XtJ/XtJ) mutant mouse, which carries a deletion in Gli3, lacks entirely CA, DG and plexus choroideus of the lateral ventricle. The targets of GLI3 are WNT ligand genes including Wnt3a, Wnt8b and Wnt9a as well as several modulators of WNT signaling, like the WNT signaling pathway inhibitor Dickkopf 2 (Dkk2), APC down-regulated 1 (Apcdd1), Rspo1-3 and Sfrp1 (HasenpuschTheil et al., 2012). Except for Sfrp1, the expression of these genes is restricted to the $\mathrm{CH}$ (Rspo3 shows additional weak expression in hippocampal progenitors adjacent to the $\mathrm{CH}$ and in CR cells).

\section{Emx2}

Transcription factor gene Emx2 is expressed within the diencephalon roof with a caudo-rostral gradient (Simeone et al., 1992). Emx2 is essential for the development of the DG, and mouse embryos deficient in Emx2 completely lack a DG (Pellegrini et al., 1996; Oldekamp et al., 2004a). A defect in the cortical positional information-signal cascade, which is transduced by FGF8 and probably WNT proteins, might be the cause of the phenotype (Muzio et al., 2002; Fukuchi-Shimogori and Grove, 2001; Ligon et al., 2003; Shimogori et al., 2004). CR cells in the marginal zone of the DG, which also express $E m \times 2$, are reduced in number in Emx2-deficient mouse brains (Mallamaci et al., 1998, 2000). The Emx2-expressing cells of the DG neuroepithelium coexpress Neurogenin1 (Neurog1), neurogenin 2 (Neurog2) and T-box TF2 (Tbr2; see below).

\section{Neurog2}

Neurog2 is a bHLH transcription factor gene with proneural function expressed in the embryonic neuroepithelium. It promotes the neuronal fate in multipotent stem cells. Neurog2 activates the expression of several neuronal differentiation genes, e.g., the NeuroD family of transcription factors (Seo et al., 2007; Wilkinson et al., 2013), and it plays a crucial role in the differentiation of glutamatergic neurons (Schuurmans et al., 2004; Berninger et al., 2007; Wilkinson et al., 2013). During DG formation, all proliferative matrix precursor cells express Neurog2 (Pleasure et al., 2000; Galichet et al., 2008). Neurog2 null mutants show a severely atrophic DG at birth due to defects in DG proliferation and differentiation (Galichet et al., 2008). Although Neurog2-deficient progenitor cells expressed Ascl1 during DG morphogenesis, this gene could not compensate the lack of Neurog2 in the DG (although it can in the rest of the telencephalon; Nieto et al., 2001; Galichet et al., 2008). The glial scaffold of the Neurog2 mutant DG is malformed, causing an interrupted migration of progenitors (Galichet et al., 2008). Since the atrophic DG and disorganized glial scaffold appear also in Wnt mutant embryos, it is possible that Neurog2 acts downstream WNT signaling during DG formation (Hirabayashi et al., 2004; Zhou et al., 2004; Galichet et al., 2008).

\section{Neurod1}

The transcription factor gene Neuronal differentiation 1 (Neurod1) is a bHLH proneural gene expressed with a 
dorso-ventral gradient in the cortical plate and tertiary matrix of the DG. The DG and cerebellum are completely missing in Neurod 1 conditional knockouts (Miyata et al., 1999) because this gene is required for the survival of DG granule cells (Miyata et al., 1999; Liu et al., 2000; Schwab et al., 2000). Neurod1 overexpression causes premature neuronal maturation (Roybon et al., 2009; Boutin et al., 2010).

\section{Prox1}

Prospero homeobox 1 (Prox 1 ) is a transcription factor gene expressed by the migration stream of newly generated granule cell precursors in the secondary matrix and also by mature granule cells in the tertiary matrix of the emerging DG (Oliver et al., 1993; Oldekamp et al., 2004b; Li et al., 2009). It is therefore frequently utilized as a DG granule neuron lineage marker and plays an essential role in proliferating neuronal progenitors and granule cells in DG development (Rubin and Kessaris, 2013). Studying Prox1 null mutant mice made evident that Prox1 plays an essential role in proliferating neuronal progenitors and differentiation of granule cells in DG development (Lavado et al., 2010). Remarkably, postmitotic DG granule neurons deficient in Prox 1 trans-differentiate into CA3 pyramidal neurons (Iwano et al., 2012).

\section{Nfix}

The transcription factor nuclear factor I/X (Nfix) is necessary for NSCs to find their specific location in the emerging DG (Martynoga et al., 2013). Nfix is already intensely expressed in the DG neuroepithelium on embryonic day 14, and Nfix null mutant mice display severe defects in DG formation because of impaired differentiation of neurons and glial cells. In Nfix mutants, Prox1expressing granule neurons are reduced in number, their glial scaffold is disordered and DG morphogenesis is inappropriate (Martynoga et al., 2013; Heng et al., 2014). Nfix regulates a large number of genes, many of which influence cell motility and adhesion as well as extracellular matrix generation (Martynoga et al., 2013).

\section{Bcl11b}

Bcl11b (Ctip2) is a transcription factor gene expressed in DG granule cells. Its function affects two essential developmental processes, i.e., the proliferation and the differentiation of granule cells. Since $B c l 11 b$ is expressed in postmitotic DG granule neurons, its influence on the proliferation compartment is probably effected through secretion of a factor acting on dividing cells of the proliferation matrix (positive feedback). A direct transcriptional target of BCL11B, the cell-cell adhesion protein desmoplakin (DSP), is essential for the proper differentiation of DG granule cells (Simon et al., 2012).

\section{SOME TRANSCRIPTION FACTORS ESSENTIAL FOR DG GRANULE CELL MIGRATION (FIGURE 2)}

\section{Tbr2}

Same as Neurog2, Tbr2 is expressed in all three DG proliferative matrices by proliferating progenitor cells (Hodge et al., 2012), and its deletion inhibits the production of IPCs and granule neurons and enhances the proliferation of stem cells. This suggests that Tbr2 plays a role in the reconfiguration of stem cells into late differentiating IPCs. Tbr2 could accomplish this function by direct downregulation of Sox2, a stem cell transcription factor (Hodge et al., 2012). Tbr2 is also expressed by $\mathrm{CR}$ cells originating from the $\mathrm{CH}$; in Tbr2 mutant mice, these neurons proliferate deficiently causing abnormal DG morphogenesis (Hodge et al., 2013).

\section{Lhx5}

In LIM homeobox protein 5 (Lhx5) knockout mice, DG precursor cell migration is disturbed so that they accumulate in the neuroepithelium (VZ). This results in the absence of DG granule cells (Zhao et al., 1999). In these mutants, the fimbria and hippocampal commissures do not develop either.

\section{Lmx1a}

Lmxla is a transcription factor gene expressed in the $\mathrm{CH}$ and essential for the specification of its derivatives (Chizhikov et al., 2010). In particular, Lmxla stimulates the proliferation of CR cells, probably by repressing $L h x 2$ (Chizhikov et al., 2010). As mentioned above, Cajal-Retzius neurons secrete RELN, which in turn is essential for the DG precursors to migrate along radial glial fibers. Mouse brains deficient in $\operatorname{Lmxla}$ (the classical dreher mutant) show a DG GCL partially absent, cytoarchitectonically disorganized (Sekiguchi et al., 1992) and with gross alterations in the arrangement of axonal afferents (Sekiguchi et al., 1996).

\section{Couptf1 (Nr2f1)}

Couptf1 is a transcription factor gene expressed at every stage of DG granule cell development, i.e., dentate neuroepithelium, proliferating precursors and differentiated granule cells (Parisot et al., 2017). Couptf1 is a direct activator of the migrationrelated cytokine Cxcr4 and is essential for the formation of the radial glial fiber scaffold that supports and guides the migration of the DG precursors. Since radial glial cells (RGCs) are also responsible for the proliferation of DG precursors in the first matrix (1stM; neuroepithelium), Couptf1 is positioned at the crossroads between precursor proliferation and migration, two cellular phenomena tightly linked in the DG (Parisot et al., 2017).

\section{OTHER PROTEINS NECESSARY FOR THE MAINTENANCE OF DG GRANULE CELLS IN POSTNATAL AND ADULT STAGES: TIX AND Ccnd2}

Interesting at postnatal and adult ages are two other factors which, although not relevant during development, are required for the maintenance of the DG granule cells and worth mentioning briefly here: $T l x$ (a transcriptor factor) and $C c n d 2$ (a cyclin). While Tlx is dispensable for DG development, it is essential for adult neurogenesis from the subgranular zone 
(DG) and VZ-SVZ (fated for the olfactory bulb; Shi et al., 2004; Zhang et al., 2008; Niu et al., 2011; Murai et al., 2014). In the DG of wild-type mice, Tlx overexpression induces neurogenesis and enhances memory and learning (Murai et al., 2014), suggesting that, in NSCs, Tlx induces the transition from quiescence to activation. In addition, Tlx activates Ascl1 for induction of neuronal lineage commitment, activates WNT signal induction for NSC proliferation and regulates astrogenesis by BMP signal downregulation (Shi et al., 2004; Elmi et al., 2010; Qu et al., 2010; Qin et al., 2014). Ccnd2 is also dispensable for hippocampal development but essential for late postnatal and adult neurogenesis in the hippocampal niche (Kowalczyk et al., 2004; Shi et al., 2004; Ansorg et al., 2012). CCND2 directs the cell cycle transition between the G1 and $\mathrm{S}$ mitotic phases and is a key component of the cell cycle mechanism, together with CCND1 and CCND3 and the cyclindependent kinases (CDKs; Sherr et al., 1994; Ekholm and Reed, 2000).

\section{PROGRAMMED DIFFERENTIATION OF TELENCEPHALIC PRECURSORS AND DG NEURONS FROM ESCs}

The generation of DG granule cells in vitro, from mouse and from human tissue, has been attempted using different strategies that mimic essential cellular and molecular events of telencephalic differentiation and hippocampus development (Watanabe et al., 2005; Yu et al., 2014a; Sakaguchi et al., 2015).

The idea underlying the approaches taken by the laboratories of Sasai and Gage was to imitate normal development as close as possible (signaling pathways, growth factors, etc.,) while keeping specific cell culture conditions. Embryoid bodies (EBs) and single culture systems were used as starting point, and sometimes pre-differentiated cells were transplanted to brains in vivo for the ultimate differentiation into recognizable cell types, including DG granule cells. Both the laboratories of Sasai and Gage could generate ESC/iPSC-derived hippocampal/DGlike neurons by $3 \mathrm{D}$-culturing techniques and by applying some key growth factor modulating hippocampal development. Comparing both cultivation methods, Sakaguchi et al. (2015) focused more on the early hippocampal developmental stage. The application of the hippocampal differentiation protocols to hiPSCs from patients with hippocampal pathologies could provide new insights into neuropathology and the discovery of new targets for pharmaceutics (Yu et al., 2014b).

By using an optimized serum-free suspension culture with addition of the WNT antagonist DKK1, FOXG1-positive telencephalic cells can be generated; these can be made to express typical dorsal telencephalic markers paired box 6 (PAX6) and EMX1 by the subsequent administration of WNT3a.

One protocol based on EBs formed from hESC-derived dorsomedial telencephalic cells cultured in the presence of a combination of growth factors and BMP and WNT agonists was successful in generating two hippocampal neuronal types. One of these neuronal populations expressed the pan-hippocampal marker gene Zbtb20 as well as Prox1 (DG granule cell marker), while the other expressed $Z b t b 20$ in combination with glutamate ionotropic receptor kainate type subunit 4 (GRIK4, also known as KA1), a marker of pyramidal cells of CA. However, these cells showed immature firing patterns and did not achieve the reconstruction of the primary hippocampal neuronal circuitry: specific CA1 pyramidal neurons could not be generated, and the formation of the DG or regionally specific hippocampal tissues could not be recapitulated (Sakaguchi et al., 2015).

A third protocol imitated key steps of hippocampal development and generated a few NeuroD1-, Prox1- and Tbr1positive granule-like cells. In this protocol, hESC-derived EB were first treated with the anti-caudalizing proteins DKK1 (WNT antagonist), NOGGIN (BMP-antagonist), the ALK5 (TGFB pathway) inhibitor SB431542 and the SHH inhibitor cyclopamine. Then, WNT3a and brain-derived neurotrophic factor (BDNF) were added and co-cultures were initiated as single cell suspensions on hippocampal astrocytes. The resultant DG precursor-like cells were then transplanted into the hippocampus of brains in vivo, and their integration and maturation were followed. However, this study lacks detailed co-localization studies with DG markers, so that the final differentiation phenotypes of the DG-like cells cannot be assessed (we do not know if these cells are really granule cells; Yu et al., 2014a). Furthermore, the last stages of differentiation with this protocol could be achieved only after in vivo transplantation. This indicates that the in vitro differentiation protocols are missing key factors present in the in vivo local stem cell niche, and also argues for a closer look at these niches and their molecular mechanisms. In the same direction, it is intriguing that hiPSCs can differentiate into Prox1-positive granule-like cells with typical DG granule cell dendrites simply by co-culture with hippocampal slice cultures (Hiragi et al., 2017).

Interestingly, the differentiation protocol from $\mathrm{Yu}$ et al. (2014a) has also been applied to hiPSCs from patients with schizophrenia (Yu et al., 2014a). Here the authors observed lower levels of NeuroD1, Prox 1 and Tbr1 expression as well as reduced neuronal activity and spontaneous neurotransmitter release.

\section{ELECTROPHYSIOLOGICAL FEATURES OF IMMATURE AND MATURE GRANULE CELLS}

Immature newborn granule cells play key roles in learning and memory because of their augmented synaptic plasticity and excitability (Kempermann et al., 1997; Cameron and McKay, 2001; Ninkovic et al., 2007); on the contrary, mature granule cells are reported to be more resistant to excitatory inputs (Liu et al., 2012; Ramirez et al., 2013; Redondo et al., 2014; Ryan et al., 2015). After generating DG granule like-neurons in vitro from iPSCs it is important to determine if they show the electrophysiological features of either immature or mature in vivo DG granule cells.

Differential parameters between both kinds of neurons include intrinsic properties -input resistance (Rin), capacitance and action potential waveform-as well as synaptic properties (esp. spontaneous postsynaptic potentials/currents). 
One key neuronal parameter, the resting membrane potential $(\mathrm{Vm})$, could in principle be used to assess the functional status of neurons. However, the Vm of immature DG granule cells has been variously reported in the literature. Among others found relatively depolarized $\mathrm{Vm}$ values (around $-50 \mathrm{mV}$ ) in immature DG granule cells, and (Pedroni et al., 2014) even report -30 to $-40 \mathrm{mV}$. Careful measurements by other researchers however have yielded higher values, similar to those found for mature DG granule neurons (around $-80 \mathrm{mV}$; Schmidt-Hieber et al., 2004). Furthermore, (Mongiat et al., 2009) found $-75 \mathrm{mV}$ for immature and $-80 \mathrm{mV}$ for mature, and numerous other authors have recorded $\mathrm{Vm}$ values for immature DG granule cells similar to those of mature ones (Ge et al., 2006; Heigele et al., 2016; Li et al., 2017). These differences depend probably on the technical difficulties involved in performing patch clamp recordings on cells with very high Rin. This has been discussed in detail by Heigele and collaborators (see the "Methods" section in Heigele et al., 2016).

More agreement is found around the differential character of the Rin, which is remarkably larger for immature than mature DG granule cells. The simpler dendritic morphology, shorter axonal processes and lower expression of ion channels of immature cells enhance their Rin significantly, often up to G $\Omega$ (Schmidt-Hieber et al., 2004; Mongiat et al., 2009; Pedroni et al., 2014).

The membrane capacitance of immature DG granule cells has also been consistently found smaller than that of mature ones. The actual values and the degree of difference vary between reports. For instance, (Heigele et al., 2016) have reported $19.2 \pm 1.5$ vs. $69 \pm 5$ pF, while (Pedroni et al., 2014) found $14 \pm 1$ vs. $17 \pm 1$ pF, and (Mongiat et al., 2009) obtained $30.6 \pm$ 1 vs. $56.9 \pm 2.1 \mathrm{pF}$.

Perhaps the best approach would be to base the assessment of maturity on Rin and capacitance, instead of $\mathrm{Vm}$, which is more difficult to assess correctly on immature DG granule cells.

The waveform of the action potential becomes more narrow with maturation, probably because of a decrease of calciumspikes with superimposed action potentials. In contrast, mature adult granule cells are reported to be less excitable and their sparse firing in vivo is well known (Liu et al., 2012; Ramirez et al., 2013; Redondo et al., 2014; Ryan et al., 2015). In addition, the network activity of most of immature spiking neurons is strongly synchronized, resembling the typical giant depolarizing potentials (GDPs) of the hippocampal formation. These GDPs are generated by the synergistic actions of glutamate and GABA which are, at this immature stage, both depolarizing and excitatory (Pedroni et al., 2014).

Immature DG granule cells show a clear GABA ergic, rather than glutamatergic, phenotype (Schmidt-Hieber et al., 2004; Esposito A. et al., 2005; Pedroni et al., 2014). Transient production of GABA (expression of glutamic acid decarboxylase) and release of GABA from granule cells during maturation has been observed (Cabezas et al., 2013) and may persist, in attenuated form, into adulthood (Gutiérrez, 2016).

Immature granule cells have another specific characteristic: under physiological conditions, the transient T-type calcium conductance expression underlies a low-threshold calcium spike, which again greatly enhances the initiation of superimposed sodium spikes (Schmidt-Hieber et al., 2004). On the contrary, mature granule cells fail to produce low-threshold calcium spikes. Under pharmacologically blocked T-type channels, no significant modification could be observed in their sodium spike threshold (Schmidt-Hieber et al., 2004; Martinello et al., 2015). Mature granule cells exhibit low-threshold calcium spikes when potassium channel blockers are present (Blaxter et al., 1989), and are capable of firing action potential exacerbations under physiological conditions, unlike immature granule cells (Staley et al., 1992; Pernía-Andrade and Jonas, 2014). This fact increases the opportunities for triggering spikes in their CA3 pyramid targets (Henze et al., 2002).

In the dendrites of both mature and immature granule cells, sodium action potentials cause calcium transients with high amplitude (Schmidt-Hieber et al., 2007; Stocca et al., 2008; Hamilton et al., 2010; Krueppel et al., 2011; Kamijo et al., 2014). Yet, a more efficient transient input summation is made possible by immature granule cells, which exhibit longer transients in proximal and distal dendrites. This fact appears to be caused by lower endogenous calcium binding capacities and slower extrusion rates (Stocca et al., 2008). For mature and immature cells, variations in the calcium influx could basically enhance distinctions in synaptic plasticity.

Mature granule cell dendrites can be considered passive linear integrators with a quite intense voltage signal attenuation (Krueppel et al., 2011). In general, mature granule cells have electrophysiological features characterized by normal action potential amplitude and sparse firing (Mongiat et al., 2009), strong perisomatic GABAergic inhibition (Cupello et al., 2005; Esposito A. et al., 2005; Temprana et al., 2015), efficient calcium buffering (Stocca et al., 2008) and a high threshold for long term potentiation induction (Wang et al., 2000; Schmidt-Hieber et al., 2004; Ge et al., 2007).

Finally, let us remark that the degree of maturation of DG granule cells generated in vitro can be enhanced by co-culture with hippocampal astrocytes and/or neurons, or by culturing them on the GCL of hippocampal organotypical slices.

\section{GRANULE NEURONS OF THE DG: PATHOLOGIES AND MODELS}

\section{Granule Neurons of the DG in Disease}

A number of neuropathological defects causing higher cognitive dysfunction are concomitant with abnormal hippocampal neurogenesis and plasticity (Xu C. J. et al., 2015). In newborn granule neurons, neurogenesis and development of irregular hilar basal dendrites are influenced by hippocampal epileptic seizures (Jessberger et al., 2007; Hattiangady and Shetty, 2010). Regular granule neurons develop dendrites towards the molecular layer and send axons through the hilus. On the contrary, dendrites from neurons that are induced by seizures appear to grow exuberantly into the hippocampal hilus instead of the molecular layer. 
In the aging brain, the decrease in hippocampal neurogenesis is due to the declining neural progenitor pool (Jessberger and Gage, 2008; Villeda et al., 2011; Spalding et al., 2013). It has been documented that deficiencies in the hippocampus are related to specific cognitive disorders: depression (Patrício et al., 2013), early stages of Alzheimer's disease (Demars et al., 2010; Faure et al., 2011; Mu and Gage, 2011; Rodríguez et al., 2011), bipolar disorder (Valvezan and Klein, 2012; Walton et al., 2012) and schizophrenia (Tamminga et al., 2010; Walton et al., 2012; Hagihara et al., 2013). Moreover, there is reason to think that the etiology and pathogenesis of schizophrenia and bipolar disorder are related to abnormal DG granule neuron maturation (Reif et al., 2006; Yamasaki et al., 2008; Walton et al., 2012; Hagihara et al., 2013; Shin et al., 2013).

NSC research has advanced very fast in the last few years, in particular in the fields of in vitro development, cellular reprogramming, cell differentiation and regenerative therapeutic techniques such as cell transplantation. Analyzing the pathways used by pluripotential stem cells (PSCs) to differentiate into particular neuronal and glial phenotypes has extended our knowledge about human brain development and maturation and will help in the future to understand certain neurological disorders. The generation of specific neuronal cell types and brain structures ex vivo will be an additional important step in brain research, to regulate the directed neuronal differentiation of crucial brain development events in stem cells and neuronal precursors.

For this reason, an exceptional opportunity for modeling neurological disorders and for drug design may be provided by the generation of DG granule neurons in vitro from the cells of patients with hippocampal CNS disorders.

\section{Induced PSCs and Models}

Harvesting central nervous system (CNS) tissue from living patients suffering brain disorders it is not possible. By using patient-derived neural induced PSCs (iPSCs), analysis of CNS disorders is now within reach of scientists and clinicians. Neural iPSCs are able to form functional neurons and glial cells; however, developing differentiation strategies for the generation of specific neurons and glia cells and their diseaserelevant subtypes is still a significant challenge. A series of breakthroughs in the field of neural human PSCs (hPSC) differentiation during the past decade, has made it possible to use iPSCs as the basis of CNS disease models (for reviews see Sandoe and Eggan, 2013; Okano and Yamanaka, 2014; Pasca et al., 2014; Srikanth and Young-Pearse, 2014). iPSC technology has already been used to generate ventral midbrain dopaminergic neurons for Parkinson disease (Perrier et al., 2004; Roy et al., 2006; Kriks et al., 2011; Ma et al., 2011; Kikuchi et al., 2017), spinal motor neurons for amyotrophic lateral sclerosis (Di Giorgio et al., 2008; Dimos et al., 2008; Marchetto et al., 2008), cortical pyramidal neurons (Shi et al., 2012; Vanderhaeghen, 2012) and forebrain interneurons (Maroof et al., 2013; Nicholas et al., 2013; Yuan et al., 2015; Sun et al., 2016).

Furthermore, it has been recently shown that so-called cerebral organoids can be generated in vitro from iPSCs.
These are 3D-cultured cells that self-assemble into brain-like structures reproducing aspects of cerebral developmental and even showing discrete regional cortical organization (Lancaster et al., 2013; Pasca et al., 2015; Renner et al., 2017; Sloan et al., 2017). Appropriately-arranged germinal zones and radial and tangential migration of cortical neurons can be seen in these organoids as well as cortical organizers such as the $\mathrm{CH}$ (Renner et al., 2017). This suggests that the organoids generate neuronal micro-environments and are self-organizing. In the present stage, the generation of dorsal forebrain structures like the hippocampus by organoids succeeds only to a limited degree. However, it presents an interesting starting point for tissue-engineering of the simplest cortical structures, including the DG.

The laboratories of Sasai and Gage were the first to obtain hippocampal and DG-like neurons from embryonic stem cells (ESCs; Watanabe et al., 2005; Yu et al., 2014a; Sakaguchi et al., 2015). In one of these studies, researchers applied a directed differentiation protocol to generate human granule-like cells by reprogramming cells from patients with schizophrenia (Yu et al., 2014a). In principle, in vivo cell therapies could be developed on the basis of this kind of patient-specific, individualized generation of DG neurons from hiPSCs. Obviously, there remains a lot of extra work to make cell transplantation into a practicable therapy. Despite these difficulties, numerous studies have applied stem cell derived neuronal transplantation successfully in animal models and achieved functional improvements. These early successes emphasize the need for further research in order to understand the exact mechanisms of function recovery after cell transplantation. This is a vital step for developing effective and safe in vivo cell therapies for human patients ( $\mathrm{Lu}$ et al., 2003; Valente et al., 2006; Wernig et al., 2008; Hargus et al., 2010; Jiang et al., 2011; Ma et al., 2013).

\section{OUTLOOK AND CRITICAL ASPECTS}

The ability to reconstruct the DG in vitro would be a major step for examining the molecular and cellular mechanisms underlying neurological disorders (such as schizophrenia, Alzheimer's disease and temporal lobe epilepsy) as well as for the screening of appropriate therapeutic drugs. The immediate goal to this end is to develop and refine protocols for the reliable production of DG granule cells from ESC- or iPSC-derived cells. The best existing method for the generation of DG granule cells in vitro with $\mathrm{EB}$ and single cell culturing is still very inefficient (Sakaguchi et al., 2015).

Dorsal telencephalic precursor cells, generated in vitro and identified by co-expression of forkhead box G1 (Foxg1), Gli3, Emx2 and Ascl1 should provide the starting cell source for the directed differentiation of DG granule cells. Guiding the differentiation of neurons with dorsal telencephalic phenotype through various embryonic stages towards the DG granule neuron phenotype will require a strict following of the key developmental events, starting with the sequential administration of appropriate growth factors and transcription factors, mimicking the differentiation of the DG neuroepithelium 
towards the different proliferation matrices and finally immature and mature granule cells. Major immediate challenges concern the scheduling and titration of these factors. In this context, it would be most interesting to analyze possible synergistic effects of BMP7 and WNT3a on the production of Emx2/Lef1expressing IPCs and of the Prox1/NeuroD1/Calb2-expressing neurons that they generate during DG granule cell differentiation in vitro. IPC differentiation into DG granule cells is enhanced by expression of key transcription factors, particularly Emx2, Neurog2, Tbr2, NeuroD1, Lef1 and Prox1 (Hodge et al., 2008, 2012).

DG granule cell differentiation could also be forced by sequential and coordinated expression of the essential transcription factors. Obviously, when attempting to differentiate neuronal stem cells into granule cells in vitro, expression of the key dorsal telencephalic transcription factors needs to be activated in a sequence and time course analogous to those that occur during normal brain development (Li and Pleasure, 2005, 2007). Possible sources of error when assessing the results of protocols for in vitro production of DG granule cells are other neurons expressing similar combinations of transcription factors. For instance, the combination Emx2-Tbr2-NeuroD1-Lef1 is also expressed by pyramidal cells of the CA, and Emx2Tbr2 are also expressed by CR cells. Ccnd 2 and transcription factors like Nfix, Tlx and Ascl1, which play a major role in postnatal and adult granule cell neurogenesis, will have to be tested for their influence on the proliferation and maintenance of already generated granule cell precursors as well as differentiated granule cells.

Ultimately, single cell expression profiling of cells marked with stage-specific reporter constructs could be needed in order to molecularly define with precision the differentiation stages of granule cells in vivo and in vitro. Subsequently, conditional overexpression of transcription factors during the directed differentiation of PSCs towards DG granule precursor could be attempted. Lineage tracing of the different stages of granule cell development in combination with single cell expression profiling would be of importance to analyze the sequence of molecular events determining granule cell fate.

Alternatively, the cellular engineering of organizers such as the $\mathrm{CH}$ could be attempted. However, the 3-D cultivation of neuronal tissues in vitro is a major challenge, particularly for complex regions of the nervous system (Watanabe et al., 2005; Yu et al., 2014a; Sakaguchi et al., 2015; Renner et al., 2017). The ultimate goal will be the generation of 3-D hippocampal organoids (Eiraku et al., 2008; Nakano et al., 2012; Kadoshima et al., 2013; Lancaster et al., 2013; Sasai, 2013a,b; Renner et al., 2017) or at least the reproduction of hippocampal microcircuits on micro-patterned fluidic plates.

\section{REFERENCES}

Abrous, D. N., and Wojtowicz, J. M. (2015). Interaction between neurogenesis and hippocampal memory system: new vistas. Cold Spring Harb. Perspect. Biol. 7:a018952. doi: 10.1101/cshperspect.a018952

Altman, J., and Bayer, S. A. (1990). Migration and distribution of two populations of hippocampal granule cell precursors during the perinatal and postnatal periods. J. Comp. Neurol. 301, 365-381. doi: 10.1002/cne.903010304
Finally, further characterization of the molecular guidance cues of DG granule cells, in vivo and in vitro, is essential to elaborate protocols generating viable, transplantable neuronal cells; consider for instance the problems posed by the axonal growth-inhibiting milieu of the adult nervous systems (Skutella and Nitsch, 2001; Ng et al., 2013; Senzai and Buzsáki, 2017). When performing neuronal cell therapy after brain traumata or neurodegenerative disorders, it is crucial to deliver the transplanted cells to the exact location of damage and to integrate them physiologically and functionally. For the generation of appropriate neuronal connections, the transplanted cells have to develop dendrites and axons able to find their appropriate functional partners and interact with them. At the end of the process, the transplanted cells need to be functionally integrated into the respective neuronal circuit.

Growth-inhibition factors for re-growing axons and dendrites in the adult CNS post-lesion make this integration process difficult. Therefore, it is essential to support the outgrowth and navigation of neuronal processes and their integration in the existing entorhinal-DG-CA circuitry. This can be attempted by administering anti-myelin-associated factors (Xu L. et al., 2015). The functional implications of the three myelinderived inhibitors NogoA (reticulon 4, Rtn4), myelin-associated glycoprotein and oligodendrocyte-myelin glycoprotein as well as a number of axon guidance molecules that control the survival, proliferation, migration and differentiation of NSCs has been reviewed recently (Song et al., 2018).

Despite of all accomplishments in this field, a long way is still ahead for the generation of in vitro differentiated neurons identical to their natural models.

\section{AUTHOR CONTRIBUTIONS}

$\mathrm{MH}$ and SC drafted the article. GA-B and TS wrote the final version. PN drew the Figure.

\section{FUNDING}

We gratefully acknowledge financial support by the Deutsche Forschungsgemeinschaft within the funding programme Open Access Publishing, by the Baden-Württemberg Ministry of Science, Research and the Arts and by the Ruprecht-KarlsUniversität Heidelberg.

\section{ACKNOWLEDGMENTS}

We thank Prof. Dr. Andreas Draguhn for his help in writing the section about electrophysiological features of immature and mature granule cells.

Andersen, P., Bliss, T. V., and Skrede, K. K. (1971). Lamellar organization of hippocampal pathways. Exp. Brain Res. 13, 222-238. doi: 10.1007/bf002 34087

Andersen, P., Holmqvist, B., and Voorhoeve, P. E. (1966). Excitatory synapses on hippocampal apical dendrites activated by entorhinal stimulation. Acta Physiol. Scand. 66, 461-472. doi: 10.1111/j.1748-1716.1966.tb03224.x

Ansorg, A., Witte, O. W., and Urbach, A. (2012). Age-dependent kinetics of dentate gyrus neurogenesis in the absence of 
cyclin D2. BMC Neurosci. 13:46. doi: 10.1186/1471-2202$13-46$

Armenteros, T., Andreu, Z., Hortigüela, R., Lie, D. C., and Mira, H. (2018). BMP and WNT signalling cooperate through LEF1 in the neuronal specification of adult hippocampal neural stem and progenitor cells. Sci. Rep. 8:9241. doi: 10.1038/s41598-018-27581-0

Bagri, A., Gurney, T., He, X., Zou, Y. R., Littman, D. R., Tessier-Lavigne, M., et al. (2002). The chemokine SDF1 regulates migration of dentate granule cells. Development $129,4249-4260$.

Bayer, S. A. (1980a). Development of the hippocampal region in the rat. I. Neurogenesis examined with $3 \mathrm{H}$-thymidine autoradiography. J. Comp. Neurol. 190, 87-114. doi: 10.1002/cne.901900107

Bayer, S. A. (1980b). Development of the hippocampal region in the rat. II. Morphogenesis during embryonic and early postnatal life. J. Comp. Neurol. 190, 115-134. doi: 10.1002/cne.901900108

Berninger, B., Costa, M. R., Koch, U., Schroeder, T., Sutor, B., Grothe, B., et al. (2007). Functional properties of neurons derived from in vitro reprogrammed postnatal astroglia. J. Neurosci. 27, 8654-8664. doi: 10.1523/JNEUROSCI.161507.2007

Blaxter, T. J., Carlen, P. L., and Niesen, C. (1989). Pharmacological and anatomical separation of calcium currents in rat dentate granule neurones in vitro. J. Physiol. 412, 93-112. doi: 10.1113/jphysiol.1989.sp017605

Bonaguidi, M. A., McGuire, T., Hu, M., Kan, L., Samanta, J., and Kessler, J. A. (2005). LIF and BMP signaling generate separate and discrete types of GFAP-expressing cells. Development 132, 5503-5514. doi: 10.1242/dev.02166

Bonaguidi, M. A., Peng, C. Y., McGuire, T., Falciglia, G., Gobeske, K. T., Czeisler, C., et al. (2008). Noggin expands neural stem cells in the adult hippocampus. J. Neurosci. 28, 9194-9204. doi: 10.1523/JNEUROSCI.331407.2008

Bond, A. M., Peng, C. Y., Meyers, E. A., McGuire, T., Ewaleifoh, O., and Kessler, J. A. (2014). BMP signaling regulates the tempo of adult hippocampal progenitor maturation at multiple stages of the lineage. Stem Cells 32, 2201-2214. doi: 10.1002/stem.1688

Boutin, C., Hardt, O., de Chevigny, A., Coré, N., Goebbels, S., Seidenfaden, R., et al. (2010). NeuroD1 induces terminal neuronal differentiation in olfactory neurogenesis. Proc. Natl. Acad. Sci. U S A 107, 1201-1206. doi: 10.1073/pnas. 0909015107

Brunne, B., Zhao, S., Derouiche, A., Herz, J., May, P., Frotscher, M., et al. (2010). Origin, maturation, and astroglial transformation of secondary radial glial cells in the developing dentate gyrus. Glia 58, 1553-1569. doi: 10.1002/glia.21029

Cabezas, C., Irinopoulou, T., Cauli, B., and Poncer, J. C. (2013). Molecular and functional characterization of GAD67-expressing, newborn granule cells in mouse dentate gyrus. Front. Neural Circuits 7:60. doi: 10.3389/fncir.2013.00060

Cameron, H. A., and McKay, R. D. (2001). Adult neurogenesis produces a large pool of new granule cells in the dentate gyrus. J. Comp. Neurol. 435, 406-417. doi: $10.1002 /$ cne. 1040

Caronia, G., Wilcoxon, J., Feldman, P., and Grove, E. A. (2010). Bone morphogenetic protein signaling in the developing telencephalon controls formation of the hippocampal dentate gyrus and modifies fear-related behavior. J. Neurosci. 30, 6291-6301. doi: 10.1523/JNEUROSCI.0550-10.2010

Cheng, X., Hsu, C.-M., Currle, D. S., Hu, J. S., Barkovich, A. J., and Monuki, E. S. (2006). Central roles of the roof plate in telencephalic development and holoprosencephaly. J. Neurosci. 26, 7640-7649. doi: 10.1523/JNEUROSCI. 0714-06.2006

Chenn, A., and Walsh, C. A. (2002). Regulation of cerebral cortical size by control of cell cycle exit in neural precursors. Science 297, 365-369. doi: 10.1126/science.1074192

Chizhikov, V. V., Lindgren, A. G., Mishima, Y., Roberts, R. W., Aldinger, K. A., Miesegaes, G. R., et al. (2010). Lmxla regulates fates and location of cells originating from the cerebellar rhombic lip and telencephalic cortical hem. Proc. Natl. Acad. Sci. U S A 107, 10725-10730. doi: 10.1073/pnas.0910786107

Choe, Y., Kozlova, A., Graf, D., and Pleasure, S. J. (2013). Bone morphogenic protein signaling is a major determinant of dentate development. J. Neurosci. 33, 6766-6775. doi: 10.1523/JNEUROSCI.0128-13.2013

Christian, K. M., Song, H., and Ming, G. L. (2014). Functions and dysfunctions of adult hippocampal neurogenesis. Annu. Rev. Neurosci. 37, 243-262. doi: 10.1146/annurev-neuro-071013-014134

Cupello, A., Esposito, A., Marchetti, C., Pellistri, F., and Robello, M. (2005). Calcium accumulation in neurites and cell bodies of rat cerebellar granule cells in culture: effects on $\mathrm{GABA}_{A}$ receptor function. Amino Acids 28, 177-182. doi: 10.1007/s00726-005-0165-1

Dayer, A. G., Ford, A. A., Cleaver, K. M., Yassaee, M., and Cameron, H. A. (2003). Short-term and long-term survival of new neurons in the rat dentate gyrus. J. Comp. Neurol. 460, 563-572. doi: 10.1002/cne.10675

Del Río, J. A., Heimrich, B., Borrell, V., Förster, E., Drakew, A., Alcántara, S., et al. (1997). A role for Cajal-Retzius cells and reelin in the development of hippocampal connections. Nature 385, 70-74. doi: 10.1038/385070a0

Demars, M., Hu, Y. S., Gadadhar, A., and Lazarov, O. (2010). Impaired neurogenesis is an early event in the etiology of familial Alzheimer's disease in transgenic mice. J. Neurosci. Res. 88, 2103-2117. doi: 10.1002/jnr. 22387

Di Giorgio, F. P., Boulting, G. L., Bobrowicz, S., and Eggan, K. C. (2008). Human embryonic stem cell-derived motor neurons are sensitive to the toxic effect of glial cells carrying an ALS-causing mutation. Cell Stem Cell 3, 637-648. doi: 10.1016/j.stem.2008.09.017

Dimos, J. T., Rodolfa, K. T., Niakan, K. K., Weisenthal, L. M., Mitsumoto, H., Chung, W., et al. (2008). Induced pluripotent stem cells generated from patients with ALS can be differentiated into motor neurons. Science 321, 1218-1221. doi: 10.1126/science.1158799

Drapeau, E., and Nora Abrous, D. (2008). Stem cell review series: role of neurogenesis in age-related memory disorders. Aging Cell 7, 569-589. doi: 10.1111/j.1474-9726.2008.00369.x

Eiraku, M., Watanabe, K., Matsuo-Takasaki, M., Kawada, M., Yonemura, S., Matsumura, M., et al. (2008). Self-organized formation of polarized cortical tissues from ESCs and its active manipulation by extrinsic signals. Cell Stem Cell 3, 519-532. doi: 10.1016/j.stem.2008.09.002

Ekholm, S. V., and Reed, S. I. (2000). Regulation of $\mathrm{G}_{1}$ cyclin-dependent kinases in the mammalian cell cycle. Curr. Opin. Cell Biol. 12, 676-684. doi: 10.1016/s0955-0674(00)00151-4

Elmi, M., Matsumoto, Y., Zeng, Z. J., Lakshminarasimhan, P., Yang, W., Uemura, A., et al. (2010). TLX activates MASH1 for induction of neuronal lineage commitment of adult hippocampal neuroprogenitors. Mol. Cell. Neurosci. 45, 121-131. doi: 10.1016/j.mcn.2010.06.003

Esposito, A., Robello, M., Pellistri, F., and Marchetti, C. (2005). Two-photon analysis of lead accumulation in rat cerebellar granule neurons. Neurochem. Res. 30, 949-954. doi: 10.1007/s11064-005-5980-y

Espósito, M. S., Piatti, V. C., Laplagne, D. A., Morgenstern, N. A., Ferrari, C. C., Pitossi, F. J., et al. (2005). Neuronal differentiation in the adult hippocampus recapitulates embryonic development. J. Neurosci. 25, 10074-10086. doi: 10.1523/JNEUROSCI.3114-05.2005

Fan, X., Xu, H., Cai, W., Yang, Z., and Zhang, J. (2003). Spatial and temporal patterns of expression of Noggin and BMP4 in embryonic and postnatal rat hippocampus. Dev. Brain Res. 146, 51-58. doi: 10.1016/j.devbrainres.2003. 09.007

Faure, A., Verret, L., Bozon, B., El Tannir El Tayara, N., Ly, M., Kober, F., et al. (2011). Impaired neurogenesis, neuronal loss, and brain functional deficits in the APPxPS1-Ki mouse model of Alzheimer's disease. Neurobiol. Aging 32, 407-418. doi: 10.1016/j.neurobiolaging.2009.03.009

Favaro, R., Valotta, M., Ferri, A. L., Latorre, E., Mariani, J., Giachino, C., et al. (2009). Hippocampal development and neural stem cell maintenance require Sox2-dependent regulation of Shh. Nat. Neurosci. 12, 1248-1256. doi: $10.1038 / \mathrm{nn} .2397$

Fernandes, M., Gutin, G., Alcorn, H., McConnell, S. K., and Hébert, J. M. (2007). Mutations in the BMP pathway in mice support the existence of two molecular classes of holoprosencephaly. Development 134, 3789-3794. doi: 10.1242/dev. 004325

Förster, E., Tielsch, A., Saum, B., Weiss, K. H., Johanssen, C., Graus-Porta, D., et al (2002). Reelin, Disabled 1 , and $\beta 1$ integrins are required for the formation of the radial glial scaffold in the hippocampus. Proc. Natl. Acad. Sci. U S A 99, 13178-13183. doi: 10.1073/pnas.202035899

Fukuchi-Shimogori, T., and Grove, E. A. (2001). Neocortex patterning by the secreted signaling molecule FGF8. Science 294, 1071-1074. doi: $10.1126 /$ science. 1064252

Furuta, Y., Piston, D. W., and Hogan, B. L. (1997). Bone morphogenetic proteins (BMPs) as regulators of dorsal forebrain development. Development 124 2203-2212.

Galceran, J., Fariñas, I., Depew, M. J., Clevers, H., and Grosschedl, R. (1999). Wnt3a-/- like phenotype and limb deficiency in 
Lef1 ${ }^{-/-}$Tcf1 ${ }^{-/-}$mice. Genes Dev. 13, 709-717. doi: 10.1101/gad.13. 6.709

Galceran, J., Miyashita-Lin, E. M., Devaney, E., Rubenstein, J. L., and Grosschedl, R. (2000). Hippocampus development and generation of dentate gyrus granule cells is regulated by LEF1. Development 127, 469-482.

Galichet, C., Guillemot, F., and Parras, C. M. (2008). Neurogenin 2 has an essential role in development of the dentate gyrus. Development 135, 2031-2041. doi: 10.1242/dev.015115

Ge, S., Goh, E. L., Sailor, K. A., Kitabatake, Y., Ming, G. L., and Song, H. (2006). GABA regulates synaptic integration of newly generated neurons in the adult brain. Nature 439, 589-593. doi: 10.1038/nature04404

Ge, S., Yang, C. H., Hsu, K. S., Ming, G. L., and Song, H. (2007). A critical period for enhanced synaptic plasticity in newly generated neurons of the adult brain. Neuron 54, 559-566. doi: 10.1016/j.neuron.2007.05.002

Gould, E., Beylin, A., Tanapat, P., Reeves, A., and Shors, T. J. (1999). Learning enhances adult neurogenesis in the hippocampal formation. Nat. Neurosci. 2, 260-265. doi: 10.1038/6365

Gross, R. E., Mehler, M. F., Mabie, P. C., Zang, Z., Santschi, L., and Kessler, J. A. (1996). Bone morphogenetic proteins promote astroglial lineage commitment by mammalian subventricular zone progenitor cells. Neuron 17, 595-606. doi: 10.1016/s0896-6273(00)80193-2

Grove, E. A., and Fukuchi-Shimogori, T. (2003). Generating the cerebral cortical area map. Annu. Rev. Neurosci. 26, 355-380. doi: 10.1146/annurev.neuro.26. 041002.131137

Grove, E. A., and Tole, S. (1999). Patterning events and specification signals in the developing hippocampus. Cereb. Cortex 9, 551-561. doi: 10.1093/cercor/9. 6.551

Grove, E. A., Tole, S., Limon, J., Yip, L., and Ragsdale, C. W. (1998). The hem of the embryonic cerebral cortex is defined by the expression of multiple Wnt genes and is compromised in Gli3-deficient mice. Development 125, 2315-2325.

Gu, Y., Arruda-Carvalho, M., Wang, J., Janoschka, S. R., Josselyn, S. A., Frankland, P. W., et al. (2012). Optical controlling reveals time-dependent roles for adult-born dentate granule cells. Nat. Neurosci. 15, 1700-1706. doi: $10.1038 /$ nn.3260

Gutiérrez, R. (2016). The plastic neurotransmitter phenotype of the hippocampal granule cells and of the moss in their messy fibers. J. Chem. Neuroanat. 73, 9-20. doi: 10.1016/j.jchemneu.2015.11.007

Hagihara, H., Takao, K., Walton, N. M., Matsumoto, M., and Miyakawa, T. (2013). Immature dentate gyrus: an endophenotype of neuropsychiatric disorders. Neural Plast. 2013:318596. doi: 10.1155/2013/318596

Hamilton, T. J., Wheatley, B. M., Sinclair, D. B., Bachmann, M., Larkum, M. E., and Colmers, W. F. (2010). Dopamine modulates synaptic plasticity in dendrites of rat and human dentate granule cells. Proc. Natl. Acad. Sci. U S A 107, 18185-18190. doi: 10.1073/pnas.1011558107

Han, J. K., Lee, H. S., Yang, H. M., Hur, J., Jun, S. I., Kim, J. Y., et al. (2008). Peroxisome proliferator-activated receptor-delta agonist enhances vasculogenesis by regulating endothelial progenitor cells through genomic and nongenomic activations of the phosphatidylinositol 3-kinase/Akt pathway. Circulation 118, 1021-1033. doi: 10.1161/circulationaha.108. 777169

Hargus, G., Cooper, O., Deleidi, M., Levy, A., Lee, K., Marlow, E., et al. (2010). Differentiated Parkinson patient-derived induced pluripotent stem cells grow in the adult rodent brain and reduce motor asymmetry in Parkinsonian rats. Proc. Natl. Acad. Sci. U S A 107, 15921-15926. doi: 10.1073/pnas.10102 09107

Hasenpusch-Theil, K., Magnani, D., Amaniti, E. M., Han, L., Armstrong, D., and Theil, T. (2012). Transcriptional analysis of Gli3 mutants identifies Wnt target genes in the developing hippocampus. Cereb. Cortex 22, 2878-2893. doi: $10.1093 /$ cercor/bhr365

Hattiangady, B., and Shetty, A. K. (2010). Decreased neuronal differentiation of newly generated cells underlies reduced hippocampal neurogenesis in chronic temporal lobe epilepsy. Hippocampus 20, 97-112. doi: 10.1002/hipo. 20594

Hebert, J. M., Mishina, Y., and McConnell, S. K. (2002). BMP signaling is required locally to pattern the dorsal telencephalic midline. Neuron 35, 1029-1041. doi: 10.1016/s0896-6273(02)00900-5

Heigele, S., Sultan, S., Toni, N., and Bischofberger, J. (2016). Bidirectional GABAergic control of action potential firing in newborn hippocampal granule cells. Nat. Neurosci. 19, 263-270. doi: 10.1038/nn.4218
Heng, Y. H., McLeay, R. C., Harvey, T. J., Smith, A. G., Barry, G., Cato, K., et al. (2014). NFIX regulates neural progenitor cell differentiation during hippocampal morphogenesis. Cereb. Cortex 24, 261-279. doi: 10.1093/cercor/ bhs307

Henze, D. A., Wittner, L., and Buzsáki, G. (2002). Single granule cells reliably discharge targets in the hippocampal CA3 network in vivo. Nat. Neurosci. 5, 790-795. doi: 10.1038/nn887

Hirabayashi, Y., Itoh, Y., Tabata, H., Nakajima, K., Akiyama, T., Masuyama, N., et al. (2004). The Wnt/ $\beta$-catenin pathway directs neuronal differentiation of cortical neural precursor cells. Development 131, 2791-2801. doi: 10.1242/dev. 01165

Hiragi, T., Andoh, M., Araki, T., Shirakawa, T., Ono, T., Koyama, R., et al. (2017). Differentiation of human induced pluripotent stem cell (hiPSC)derived neurons in mouse hippocampal slice cultures. Front. Cell. Neurosci. 11:143. doi: 10.3389/fncel.2017.00143

Hodge, R. D., Garcia, A. J. III., Elsen, G. E., Nelson, B. R., Mussar, K. E., Reiner, S. L., et al. (2013). Tbr2 expression in Cajal-Retzius cells and neuronal progenitors is required for morphogenesis of the dentate gyrus. J. Neurosci. 33, 4165-4180. doi: 10.1523/JNEUROSCI.4185-12.2013

Hodge, R. D., Kowalczyk, T. D., Wolf, S. A., Encinas, J. M., Rippey, C., Enikolopov, G., et al. (2008). Intermediate progenitors in adult hippocampal neurogenesis: Tbr2 expression and coordinate regulation of neuronal output. J. Neurosci. 28, 3707-3717. doi: 10.1523/JNEUROSCI.4280-07.2008

Hodge, R. D., Nelson, B. R., Kahoud, R. J., Yang, R., Mussar, K. E., Reiner, S. L., et al. (2012). Tbr2 is essential for hippocampal lineage progression from neural stem cells to intermediate progenitors and neurons. J. Neurosci. 32, 6275-6287. doi: 10.1523/JNEUROSCI.0532-12.2012

Holden, H. M., and Gilbert, P. E. (2012). Less efficient pattern separation may contribute to age-related spatial memory deficits. Front. Aging Neurosci. 4:9. doi: 10.3389/fnagi.2012.00009

Iwano, T., Masuda, A., Kiyonari, H., Enomoto, H., and Matsuzaki, F. (2012). Proxl postmitotically defines dentate gyrus cells by specifying granule cell identity over CA3 pyramidal cell fate in the hippocampus. Development 139, 3051-3062. doi: 10.1242/dev.080002

Jessberger, S., and Gage, F. H. (2008). Stem-cell-associated structural and functional plasticity in the aging hippocampus. Psychol. Aging 23, 684-691. doi: $10.1037 / \mathrm{a} 0014188$

Jessberger, S., Zhao, C., Toni, N., Clemenson, G. D. Jr., Li, Y., and Gage, F. H. (2007). Seizure-associated, aberrant neurogenesis in adult rats characterized with retrovirus-mediated cell labeling. J. Neurosci. 27, 9400-9407. doi: 10.1523/JNEUROSCI.2002-07.2007

Jiang, N., Qi, C., Trieu, Y., Reece, D., and Chang, H. (2011). Genomic aberrations and survival of patients with light-chain-only multiple myeloma undergoing autologous stem cell transplantation. Biol. Blood Marrow Transplant. 17, 1790-1795. doi: 10.1016/j.bbmt.2011.05.009

Kadoshima, T., Sakaguchi, H., Nakano, T., Soen, M., Ando, S., Eiraku, M., et al. (2013). Self-organization of axial polarity, inside-out layer pattern, and species-specific progenitor dynamics in human ES cell-derived neocortex. Proc. Natl. Acad. Sci. U S A 110, 20284-20289. doi: 10.1073/pnas.13157 10110

Kamijo, T. C., Hayakawa, H., Fukushima, Y., Kubota, Y., Isomura, Y., Tsukada, M., et al. (2014). Input integration around the dendritic branches in hippocampal dentate granule cells. Cogn. Neurodyn. 8, 267-276. doi: 10.1007/s11571-0149280-6

Kempermann, G. (2011). Seven principles in the regulation of adult neurogenesis. Eur. J. Neurosci. 33, 1018-1024. doi: 10.1111/j.1460-9568.2011.07599.x

Kempermann, G., Kuhn, H. G., and Gage, F. H. (1997). Genetic influence on neurogenesis in the dentate gyrus of adult mice. Proc. Natl. Acad. Sci. U S A 94, 10409-10414. doi: 10.1073/pnas.94.19.10409

Khalaf-Nazzal, R., and Francis, F. (2013). Hippocampal development-old and new findings. Neuroscience 248, 225-242. doi: 10.1016/j.neuroscience.2013. 05.061

Kikuchi, T., Morizane, A., Doi, D., Magotani, H., Onoe, H., Hayashi, T., et al. (2017). Human iPS cell-derived dopaminergic neurons function in a primate Parkinson's disease model. Nature 548, 592-596. doi: 10.1038/nature23664

Knoth, R., Singec, I., Ditter, M., Pantazis, G., Capetian, P., Meyer, R. P., et al. (2010). Murine features of neurogenesis in the human hippocampus across the lifespan from 0 to 100 years. PLoS One 5:e8809. doi: 10.1371/journal.pone. 0008809 
Kowalczyk, A., Filipkowski, R. K., Rylski, M., Wilczynski, G. M., Konopacki, F. A., Jaworski, J., et al. (2004). The critical role of cyclin D2 in adult neurogenesis. J. Cell Biol. 167, 209-213. doi: 10.1083/jcb.200404181

Kriks, S., Shim, J. W., Piao, J., Ganat, Y. M., Wakeman, D. R., Xie, Z., et al. (2011). Dopamine neurons derived from human ES cells efficiently engraft in animal models of Parkinson's disease. Nature 480, 547-551. doi: 10.1038/nature 10648

Krueppel, R., Remy, S., and Beck, H. (2011). Dendritic integration in hippocampal dentate granule cells. Neuron 71, 512-528. doi: 10.1016/j.neuron.2011.05.043

Lai, K., Kaspar, B. K., Gage, F. H., and Schaffer, D. V. (2003). Sonic hedgehog regulates adult neural progenitor proliferation in vitro and in vivo. Nat. Neurosci. 6, 21-27. doi: 10.1038/nn983

Lancaster, M. A., Renner, M., Martin, C. A., Wenzel, D., Bicknell, L. S., Hurles, M. E., et al. (2013). Cerebral organoids model human brain development and microcephaly. Nature 501, 373-379. doi: 10.1038/nature 12517

Laplagne, D. A., Espósito, M. S., Piatti, V. C., Morgenstern, N. A., Zhao, C., van Praag, H., et al. (2006). Functional convergence of neurons generated in the developing and adult hippocampus. PLoS Biol. 4:e409. doi: 10.1371/journal. pbio.0040409

Lavado, A., Lagutin, O. V., Chow, L. M., Baker, S. J., and Oliver, G. (2010). Prox1 is required for granule cell maturation and intermediate progenitor maintenance during brain neurogenesis. PLoS Biol. 8:e1000460. doi: 10.1371/journal.pbio. 1000460

Lee, S. M., Tole, S., Grove, E., and McMahon, A. P. (2000). A local Wnt-3a signal is required for development of the mammalian hippocampus. Development 127, 457-467.

Lein, E. S., Hawrylycz, M. J., Ao, N., Ayres, M., Bensinger, A., Bernard, A., et al. (2007). Genome-wide atlas of gene expression in the adult mouse brain. Nature 445, 168-176. doi: 10.1038/nature 05453

Li, G., Kataoka, H., Coughlin, S. R., and Pleasure, S. J. (2009). Identification of a transient subpial neurogenic zone in the developing dentate gyrus and its regulation by Cxcl12 and reelin signaling. Development 136, 327-335. doi: $10.1242 /$ dev. 025742

Li, G., and Pleasure, S. J. (2005). Morphogenesis of the dentate gyrus: what we are learning from mouse mutants. Dev. Neurosci. 27, 93-99. doi: 10.1159/0000 85980

Li, G., and Pleasure, S. J. (2007). Genetic regulation of dentate gyrus morphogenesis. Prog. Brain Res. 163, 143-152. doi: 10.1016/S0079-6123(07) 63008-8

Li, L., Sultan, S., Heigele, S., Schmidt-Salzmann, C., Toni, N., and Bischofberger, J. (2017). Silent synapses generate sparse and orthogonal action potential firing in adult-born hippocampal granule cells. Elife 6:e23612. doi: 10.7554/eLife. 23612

Lie, D. C., Colamarino, S. A., Song, H. J., Désiré, L., Mira, H., Consiglio, A., et al. (2005). Wnt signalling regulates adult hippocampal neurogenesis. Nature 437, 1370-1375. doi: 10.1038/nature04108

Ligon, K. L., Echelard, Y., Assimacopoulos, S., Danielian, P. S., Kaing, S., Grove, E. A., et al. (2003). Loss of Emx2 function leads to ectopic expression of Wnt1 in the developing telencephalon and cortical dysplasia. Development 130, 2275-2287. doi: 10.1242/dev.00421

Lim, D. A., Tramontin, A. D., Trevejo, J. M., Herrera, D. G., García-Verdugo, J. M., and Alvarez-Buylla, A. (2000). Noggin antagonizes BMP signaling to create a niche for adult neurogenesis. Neuron 28, 713-726. doi: 10.1016/s08966273(00)00148-3

Liu, M., Pleasure, S. J., Collins, A. E., Noebels, J. L., Naya, F. J., Tsai, M. J., et al. (2000). Loss of $\beta 2 /$ NeuroD leads to malformation of the dentate gyrus and epilepsy. Proc. Natl. Acad. Sci. U S A 97, 865-870. doi: 10.1073/pnas.97.2.865

Liu, X., Ramirez, S., Pang, P. T., Puryear, C. B., Govindarajan, A., Deisseroth, K., et al. (2012). Optogenetic stimulation of a hippocampal engram activates fear memory recall. Nature 484, 381-385. doi: 10.1038/nature11028

Lopez-Rojas, J., and Kreutz, M. R. (2016). Mature granule cells of the dentate gyrus-passive bystanders or principal performers in hippocampal function? Neurosci. Biobehav. Rev. 64, 167-174. doi: 10.1016/j.neubiorev.2016. 02.021

Lu, M., Grove, E. A., and Miller, R. J. (2002). Abnormal development of the hippocampal dentate gyrus in mice lacking the CXCR4 chemokine receptor. Proc. Natl. Acad. Sci. U S A 99, 7090-7095. doi: 10.1073/pnas.092013799
Lu, D., Mahmood, A., and Chopp, M. (2003). Biologic transplantation and neurotrophin-induced neuroplasticity after traumatic brain injury. J. Head Trauma Rehabil. 18, 357-376. doi: 10.1097/00001199-200307000-00006

Ma, L., Liu, Y., and Zhang, S. C. (2011). Directed differentiation of dopamine neurons from human pluripotent stem cells. Methods Mol. Biol. 767, 411-418. doi: 10.1007/978-1-61779-201-4_30

Ma, D., Wei, H., Lu, J., Ho, S., Zhang, G., Sun, X., et al. (2013). Generation of patient-specific induced pluripotent stem cell-derived cardiomyocytes as a cellular model of arrhythmogenic right ventricular cardiomyopathy. Eur. Heart J. 34, 1122-1133. doi: 10.1093/eurheartj/ehs226

Machold, R., Hayashi, S., Rutlin, M., Muzumdar, M. D., Nery, S., Corbin, J. G., et al. (2003). Sonic hedgehog is required for progenitor cell maintenance in telencephalic stem cell niches. Neuron 39, 937-950. doi: 10.1016/s08966273(03)00561-0

Machon, O., Backman, M., Machonova, O., Kozmik, Z., Vacik, T., Andersen, L., et al. (2007). A dynamic gradient of Wnt signaling controls initiation of neurogenesis in the mammalian cortex and cellular specification in the hippocampus. Dev. Biol. 311, 223-237. doi: 10.1016/j.ydbio.2007. 08.038

Mallamaci, A., Iannone, R., Briata, P., Pintonello, L., Mercurio, S., Boncinelli, E., et al. (1998). EMX2 protein in the developing mouse brain and olfactory area. Mech. Dev. 77, 165-172. doi: 10.1016/s0925-4773(98)00141-5

Mallamaci, A., Muzio, L., Chan, C. H., Parnavelas, J., and Boncinelli, E. (2000). Area identity shifts in the early cerebral cortex of $\mathrm{Emx} 2^{-/-}$mutant mice. Nat. Neurosci. 3, 679-686. doi: 10.1038/76630

Mangale, V. S., Hirokawa, K. E., Satyaki, P. R., Gokulchandran, N., Chikbire, S., Subramanian, L., et al. (2008). Lhx2 selector activity specifies cortical identity and suppresses hippocampal organizer fate. Science 319, 304-309. doi: $10.1126 /$ science. 1151695

Marchetto, M. C., Muotri, A. R., Mu, Y., Smith, A. M., Cezar, G. G., and Gage, F. H. (2008). Non-cell-autonomous effect of human SOD1 G37R astrocytes on motor neurons derived from human embryonic stem cells. Cell Stem Cell 3, 649-657. doi: 10.1016/j.stem.2008.10.001

Maroof, A. M., Keros, S., Tyson, J. A., Ying, S. W., Ganat, Y. M., Merkle, F. T., et al. (2013). Directed differentiation and functional maturation of cortical interneurons from human embryonic stem cells. Cell Stem Cell 12, 559-572. doi: 10.1016/j.stem.2013.04.008

Martinello, K., Huang, Z., Lujan, R., Tran, B., Watanabe, M., Cooper, E. C., et al. (2015). Cholinergic afferent stimulation induces axonal function plasticity in adult hippocampal granule cells. Neuron 85, 346-363. doi: 10.1016/j.neuron. 2014.12.030

Martynoga, B., Mateo, J. L., Zhou, B., Andersen, J., Achimastou, A., Urban, N., et al. (2013). Epigenomic enhancer annotation reveals a key role for NFIX in neural stem cell quiescence. Genes Dev. 27, 1769-1786. doi: 10.1101/gad. 216804.113

McDonald, H. Y., and Wojtowicz, J. M. (2005). Dynamics of neurogenesis in the dentate gyrus of adult rats. Neurosci. Lett. 385, 70-75. doi: 10.1016/j.neulet. 2005.05.022

Mira, H., Andreu, Z., Suh, H., Lie, D. C., Jessberger, S., Consiglio, A., et al. (2010). Signaling through BMPR-IA regulates quiescence and long-term activity of neural stem cells in the adult hippocampus. Cell Stem Cell 7, 78-89. doi: $10.1016 /$ j.stem.2010.04.016

Miyata, T., Maeda, T., and Lee, J. E. (1999). NeuroD is required for differentiation of the granule cells in the cerebellum and hippocampus. Genes Dev. 13, 1647-1652. doi: 10.1101/gad.13.13.1647

Mongiat, L. A., Esposito, M. S., Lombardi, G., and Schinder, A. F. (2009). Reliable activation of immature neurons in the adult hippocampus. PLoS One 4:e5320. doi: 10.1371/journal.pone.0005320

$\mathrm{Mu}, \mathrm{Y}$., and Gage, F. H. (2011). Adult hippocampal neurogenesis and its role in Alzheimer's disease. Mol. Neurodegener. 6:85. doi: 10.1186/1750-1326-6-85

Munji, R. N., Choe, Y., Li, G., Siegenthaler, J. A., and Pleasure, S. J. (2011). Wnt signaling regulates neuronal differentiation of cortical intermediate progenitors. J. Neurosci. 31, 1676-1687. doi: 10.1523/JNEUROSCI.540410.2011

Murai, K., Qu, Q., Sun, G., Ye, P., Li, W., Asuelime, G., et al. (2014). Nuclear receptor TLX stimulates hippocampal neurogenesis and enhances learning and memory in a transgenic mouse model. Proc. Natl. Acad. Sci. U S A 111, 9115-9120. doi: 10.1073/pnas.1406779111 
Muzio, L., Di Benedetto, B., Stoykova, A., Boncinelli, E., Gruss, P., and Mallamaci, A. (2002). Emx2 and Pax6 control regionalization of the pre-neuronogenic cortical primordium. Cereb. Cortex 12, 129-139. doi: 10.1093/cercor/12.2.129

Nakano, T., Ando, S., Takata, N., Kawada, M., Muguruma, K., Sekiguchi, K., et al. (2012). Self-formation of optic cups and storable stratified neural retina from human ESCs. Cell Stem Cell 10, 771-785. doi: 10.1016/j.stem.2012. 05.009

Ng, T., Ryu, J. R., Sohn, J. H., Tan, T., Song, H., Ming, G. L., et al. (2013). Class 3 semaphorin mediates dendrite growth in adult newborn neurons through Cdk5/FAK pathway. PLoS One 8:e65572. doi: 10.1371/journal.pone.0065572

Nicholas, C. R., Chen, J., Tang, Y., Southwell, D. G., Chalmers, N., Vogt, D., et al. (2013). Functional maturation of hPSC-derived forebrain interneurons requires an extended timeline and mimics human neural development. Cell Stem Cell 12, 573-586. doi: 10.1016/j.stem.2013.04.005

Nieto, M., Schuurmans, C., Britz, O., and Guillemot, F. (2001). Neural bHLH genes control the neuronal versus glial fate decision in cortical progenitors. Neuron 29, 401-413. doi: 10.1016/s0896-6273(01)00214-8

Ninkovic, J., Mori, T., and Götz, M. (2007). Distinct modes of neuron addition in adult mouse neurogenesis. J. Neurosci. 27, 10906-10911. doi: 10.1523/JNEUROSCI.2572-07.2007

Niu, W., Zou, Y., Shen, C., and Zhang, C. L. (2011). Activation of postnatal neural stem cells requires nuclear receptor TLX. J. Neurosci. 31, 13816-13828. doi: 10.1523/JNEUROSCI.1038-11.2011

Ohkubo, Y., Uchida, A. O., Shin, D., Partanen, J., and Vaccarino, F. M. (2004). Fibroblast growth factor receptor 1 is required for the proliferation of hippocampal progenitor cells and for hippocampal growth in mouse. J. Neurosci. 24, 6057-6069. doi: 10.1523/JNEUROSCI.1140-04.2004

Okano, H., and Yamanaka, S. (2014). iPS cell technologies: significance and applications to CNS regeneration and disease. Mol. Brain 7:22. doi: 10.1186/1756-6606-7-22

Oldekamp, J., Kraemer, N., Alvarez-Bolado, G., and Skutella, T. (2004a). bHLH gene expression in the Emx2-deficient dentate gyrus reveals defective granule cells and absence of migrating precursors. Cereb. Cortex 14, 1045-1058. doi: 10.1093/cercor/bhh064

Oldekamp, J., Krämer, N., Alvarez-Bolado, G., and Skutella, T. (2004b). Expression pattern of the repulsive guidance molecules RGM A, B and C during mouse development. Gene Expr. Patterns 4, 283-288. doi: 10.1016/j.modgep.2003. 11.008

Oliver, G., Sosa-Pineda, B., Geisendorf, S., Spana, E. P., Doe, C. Q., and Gruss, P. (1993). Prox 1, a prospero-related homeobox gene expressed during mouse development. Mech. Dev. 44, 3-16. doi: 10.1016/0925-4773(93)90012-m

Opendak, M., and Gould, E. (2015). Adult neurogenesis: a substrate for experience-dependent change. Trends Cogn. Sci. 19, 151-161. doi: 10.1016/j. tics.2015.01.001

Overstreet Wadiche, L., Bromberg, D. A., Bensen, A. L., and Westbrook, G. L. (2005). GABAergic signaling to newborn neurons in dentate gyrus. J. Neurophysiol. 94, 4528-4532. doi: 10.1152/jn.00633.2005

Panchision, D. M., Pickel, J. M., Studer, L., Lee, S. H., Turner, P. A., Hazel, T. G., et al. (2001). Sequential actions of BMP receptors control neural precursor cell production and fate. Genes Dev. 15, 2094-2110. doi: 10.1101/gad.894701

Parisot, J., Flore, G., Bertacchi, M., and Studer, M. (2017). COUP-TFI mitotically regulates production and migration of dentate granule cells and modulates hippocampal Cxcr4 expression. Development 144, 2045-2058. doi: 10.1242/dev. 139949

Pasca, S. P., Panagiotakos, G., and Dolmetsch, R. E. (2014). Generating human neurons in vitro and using them to understand neuropsychiatric disease. Annu. Rev. Neurosci. 37, 479-501. doi: 10.1146/annurev-neuro-062012170328

Pasca, A. M., Sloan, S. A., Clarke, L. E., Tian, Y., Makinson, C. D., Huber, N., et al. (2015). Functional cortical neurons and astrocytes from human pluripotent stem cells in 3D culture. Nat. Methods 12, 671-678. doi: 10.1038/nmeth.3415

Patrício, P., Mateus-Pinheiro, A., Sousa, N., and Pinto, L. (2013). Re-cycling paradigms: cell cycle regulation in adult hippocampal neurogenesis and implications for depression. Mol. Neurobiol. 48, 84-96. doi: 10.1007/s12035013-8422-x

Pedroni, A., do Minh, D., Mallamaci, A., and Cherubini, E. (2014). Electrophysiological characterization of granule cells in the dentate gyrus immediately after birth. Front. Cell. Neurosci. 8:44. doi: 10.3389/fncel.2014 00044

Pellegrini, M., Mansouri, A., Simeone, A., Boncinelli, E., and Gruss, P. (1996). Dentate gyrus formation requires Emx2. Development 122, 3893-3898.

Pernía-Andrade, A. J., and Jonas, P. (2014). Theta- $\gamma$-modulated synaptic currents in hippocampal granule cells in vivo define a mechanism for network oscillations. Neuron 81, 140-152. doi: 10.1016/j.neuron.2013.09.046

Perrier, A. L., Tabar, V., Barberi, T., Rubio, M. E., Bruses, J., Topf, N., et al. (2004). Derivation of midbrain dopamine neurons from human embryonic stem cells. Proc. Natl. Acad. Sci. U S A 101, 12543-12548. doi: 10.1073/pnas. 0404700101

Pleasure, S. J., Collins, A. E., and Lowenstein, D. H. (2000). Unique expression patterns of cell fate molecules delineate sequential stages of dentate gyrus development. J. Neurosci. 20, 6095-6105. doi: 10.1523/jneurosci.20-16-06 095.2000

Qin, S., Niu, W., Iqbal, N., Smith, D. K., and Zhang, C. L. (2014). Orphan nuclear receptor TLX regulates astrogenesis by modulating BMP signaling. Front. Neurosci. 8:74. doi: 10.3389/fnins.2014.00074

Qu, Q., Sun, G., Li, W., Yang, S., Ye, P., Zhao, C., et al. (2010). Orphan nuclear receptor TLX activates $\mathrm{Wnt} / \beta$-catenin signalling to stimulate neural stem cell proliferation and self-renewal. Nat. Cell Biol. 12, 31-40. doi: 10.1038/ncb2001

Ramirez, S., Liu, X., Lin, P. A., Suh, J., Pignatelli, M., Redondo, R. L., et al. (2013). Creating a false memory in the hippocampus. Science 341, 387-391. doi: 10.1126/science.1239073

Redondo, R. L., Kim, J., Arons, A. L., Ramirez, S., Liu, X., and Tonegawa, S. (2014). Bidirectional switch of the valence associated with a hippocampal contextual memory engram. Nature 513, 426-430. doi: 10.1038/nature13725

Reif, A., Fritzen, S., Finger, M., Strobel, A., Lauer, M., Schmitt, A., et al. (2006). Neural stem cell proliferation is decreased in schizophrenia, but not in depression. Mol. Psychiatry 11, 514-522. doi: 10.1038/sj.mp.40 01791

Renner, M., Lancaster, M. A., Bian, S., Choi, H., Ku, T., Peer, A., et al. (2017). Selforganized developmental patterning and differentiation in cerebral organoids. EMBO J. 36, 1316-1329. doi: 10.15252/embj.201694700

Rickmann, M., Amaral, D. G., and Cowan, W. M. (1987). Organization of radial glial cells during the development of the rat dentate gyrus. J. Comp. Neurol. 264, 449-479. doi: 10.1002/cne.902640403

Rodríguez, J. J., Noristani, H. N., Olabarria, M., Fletcher, J., Somerville, T. D., Yeh, C. Y., et al. (2011). Voluntary running and environmental enrichment restores impaired hippocampal neurogenesis in a triple transgenic mouse model of Alzheimer's disease. Curr. Alzheimer Res. 8, 707-717. doi: 10.2174/156720511797633214

Roy, N. S., Cleren, C., Singh, S. K., Yang, L., Beal, M. F., and Goldman, S. A. (2006) Functional engraftment of human ES cell-derived dopaminergic neurons enriched by coculture with telomerase-immortalized midbrain astrocytes. Nat. Med. 12, 1259-1268. doi: 10.1038/nm1495

Roybon, L., Hjalt, T., Stott, S., Guillemot, F., Li, J. Y., and Brundin, P. (2009). Neurogenin2 directs granule neuroblast production and amplification while NeuroD1 specifies neuronal fate during hippocampal neurogenesis. PLoS One 4:e4779. doi: 10.1371/journal.pone.0004779

Rubenstein, J. L., and Beachy, P. A. (1998). Patterning of the embryonic forebrain. Curr. Opin. Neurobiol. 8, 18-26. doi: 10.1016/S0959-4388(98)80004-4

Rubin, A. N., and Kessaris, N. (2013). PROX1: a lineage tracer for cortical interneurons originating in the lateral/caudal ganglionic eminence and preoptic area. PLoS One 8:e77339. doi: 10.1371/journal.pone.0077339

Ryan, T. J., Roy, D. S., Pignatelli, M., Arons, A., and Tonegawa, S. (2015). Memory. Engram cells retain memory under retrograde amnesia. Science 348 1007-1013. doi: 10.1126/science.aaa5542

Sahay, A., Wilson, D. A., and Hen, R. (2011). Pattern separation: a common function for new neurons in hippocampus and olfactory bulb. Neuron 70 , 582-588. doi: 10.1016/j.neuron.2011.05.012

Sakaguchi, H., Kadoshima, T., Soen, M., Narii, N., Ishida, Y., Ohgushi, M., et al. (2015). Generation of functional hippocampal neurons from self-organizing human embryonic stem cell-derived dorsomedial telencephalic tissue. Nat. Commun. 6:8896. doi: 10.1038/ncomms9896

Sandoe, J., and Eggan, K. (2013). Opportunities and challenges of pluripotent stem cell neurodegenerative disease models. Nat. Neurosci. 16, 780-789. doi: $10.1038 / \mathrm{nn} .3425$ 
Sasai, Y. (2013a). Cytosystems dynamics in self-organization of tissue architecture. Nature 493, 318-326. doi: 10.1038/nature11859

Sasai, Y. (2013b). Next-generation regenerative medicine: organogenesis from stem cells in 3D culture. Cell Stem Cell 12, 520-530. doi: 10.1016/j.stem.2013. 04.009

Schlessinger, A. R., Cowan, W. M., and Gottlieb, D. I. (1975). An autoradiographic study of the time of origin and the pattern of granule cell migration in the dentate gyrus of the rat. J. Comp. Neurol. 159, 149-175. doi: 10.1002/cne. 901590202

Schmidt-Hieber, C., Jonas, P., and Bischofberger, J. (2004). Enhanced synaptic plasticity in newly generated granule cells of the adult hippocampus. Nature 429, 184-187. doi: 10.1038 /nature 02553

Schmidt-Hieber, C., Jonas, P., and Bischofberger, J. (2007). Subthreshold dendritic signal processing and coincidence detection in dentate gyrus granule cells. J. Neurosci. 27, 8430-8441. doi: 10.1523/JNEUROSCI.178707.2007

Schuurmans, C., Armant, O., Nieto, M., Stenman, J. M., Britz, O., Klenin, N., et al. (2004). Sequential phases of cortical specification involve neurogenindependent and -independent pathways. EMBO J. 23, 2892-2902. doi: 10.1038/sj.emboj.7600278

Schwab, M. H., Bartholomae, A., Heimrich, B., Feldmeyer, D., DruffelAugustin, S., Goebbels, S., et al. (2000). Neuronal basic helix-loop-helix proteins (NEX and $\beta 2 /$ Neuro $D$ ) regulate terminal granule cell differentiation in the hippocampus. J. Neurosci. 20, 3714-3724. doi: 10.1523/jneurosci.20-1003714.2000

Scott, I. C., Steiglitz, B. M., Clark, T. G., Pappano, W. N., and Greenspan, D. S. (2000). Spatiotemporal expression patterns of mammalian chordin during postgastrulation embryogenesis and in postnatal brain. Dev. Dyn. 217, 449-456. doi: 10.1002/(sici)1097-0177(200004)217:4<449::aid-dvdy12>3.0.co;2-8

Seib, D. R., and Martin-Villalba, A. (2015). Neurogenesis in the normal ageing hippocampus: a mini-review. Gerontology 61, 327-335. doi: 10.1159/0003 68575

Senzai, Y., and Buzsáki, G. (2017). Physiological properties and behavioral correlates of hippocampal granule cells and mossy cells. Neuron 93, 691.e5-704.e5. doi: 10.1016/j.neuron.2016.12.011

Sekiguchi, M., Abe, H., Nagato, Y., Tanaka, O., Guo, H., and Nowakowski, R. S. (1996). The abnormal distribution of mossy fiber bundles and morphological abnormalities in hippocampal formation of $\operatorname{dreher}^{\mathrm{J}}\left(\mathrm{dr}^{\mathrm{J}} / \mathrm{dr}^{\mathrm{J}}\right)$ mouse. Dev. Brain Res. 92, 31-38. doi: 10.1016/0165-3806(95)00195-6

Sekiguchi, M., Shimai, K., Guo, H., and Nowakowski, R. S. (1992). Cytoarchitectonic abnormalities in hippocampal formation and cerebellum of dreher mutant mouse. Dev. Brain Res. 67, 105-112. doi: 10.1016/01653806(92)90030-z

Seo, S., Lim, J. W., Yellajoshyula, D., Chang, L. W., and Kroll, K. L. (2007). Neurogenin and NeuroD direct transcriptional targets and their regulatory enhancers. EMBO J. 26, 5093-5108. doi: 10.1038/sj.emboj.7601923

Sherr, C. J., Kato, J., Quelle, D. E., Matsuoka, M., and Roussel, M. F. (1994). D-type cyclins and their cyclin-dependent kinases: G1 phase integrators of the mitogenic response. Cold Spring Harb. Symp. Quant. Biol. 59, 11-19. doi: 10.1101/sqb.1994.059.01.004

Shi, Y., Lie Chichung, D., Taupin, P., Nakashima, K., Ray, J., Yu, R. T., et al. (2004). Expression and function of orphan nuclear receptor TLX in adult neural stem cells. Nature 427, 78-83. doi: 10.1038/nature02211

Shi, Y., Kirwan, P., and Livesey, F. J. (2012). Directed differentiation of human pluripotent stem cells to cerebral cortex neurons and neural networks. Nat. Protoc. 7, 1836-1846. doi: 10.1038/nprot.2012.116

Shimogori, T., Banuchi, V., Ng, H. Y., Strauss, J. B., and Grove, E. A. (2004). Embryonic signaling centers expressing BMP, WNT and FGF proteins interact to pattern the cerebral cortex. Development 131, 5639-5647. doi: 10.1242/dev. 01428

Shin, R., Kobayashi, K., Hagihara, H., Kogan, J. H., Miyake, S., Tajinda, K., et al. (2013). The immature dentate gyrus represents a shared phenotype of mouse models of epilepsy and psychiatric disease. Bipolar Disord. 15, 405-421. doi: 10.1111/bdi.12064

Sierra, A., Encinas, J. M., Deudero, J. J., Chancey, J. H., Enikolopov, G., Overstreet-Wadiche, L. S., et al. (2010). Microglia shape adult hippocampal neurogenesis through apoptosis-coupled phagocytosis. Cell Stem Cell 7, 483-495. doi: 10.1016/j.stem.2010.08.014
Simeone, A., Acampora, D., Gulisano, M., Stornaiuolo, A., and Boncinelli, E. (1992). Nested expression domains of four homeobox genes in developing rostral brain. Nature 358, 687-690. doi: 10.1038/358687a0

Simon, R., Brylka, H., Schwegler, H., Venkataramanappa, S., Andratschke, J., Wiegreffe, C., et al. (2012). A dual function of Bcl11b/Ctip2 in hippocampal neurogenesis. EMBO J. 31, 2922-2936. doi: 10.1038/emboj.2012.142

Skutella, T., and Nitsch, R. (2001). New molecules for hippocampal development. Trends Neurosci. 24, 107-113. doi: 10.1016/s0166-2236(00)01717-3

Sloan, S. A., Darmanis, S., Huber, N., Khan, T. A., Birey, F., Caneda, C., et al. (2017). Human astrocyte maturation captured in 3D cerebral cortical spheroids derived from pluripotent stem cells. Neuron 95, 779.e6-790.e6. doi: 10.1016/j. neuron.2017.07.035

Song, X. J., Han, W., He, R., Li, T. Y., Xie, L. L., Cheng, L., et al. (2018). Alterations of hippocampal myelin sheath and axon sprouting by status convulsion and regulating lingo-1 expression with RNA interference in immature and adult rats. Neurochem. Res. 43, 721-735. doi: 10.1007/s11064-0182474-2

Spalding, K. L., Bergmann, O., Alkass, K., Bernard, S., Salehpour, M., Huttner, H. B., et al. (2013). Dynamics of hippocampal neurogenesis in adult humans. Cell 153, 1219-1227. doi: 10.1016/j.cell.2013.05.002

Srikanth, P., and Young-Pearse, T. L. (2014). Stem cells on the brain: modeling neurodevelopmental and neurodegenerative diseases using human induced pluripotent stem cells. J. Neurogenet. 28, 5-29. doi: 10.3109/01677063.2014. 881358

Staley, K. J., Otis, T. S., and Mody, I. (1992). Membrane properties of dentate gyrus granule cells: comparison of sharp microelectrode and whole-cell recordings. J. Neurophysiol. 67, 1346-1358. doi: 10.1152/jn.1992.67.5.1346

Stocca, G., Schmidt-Hieber, C., and Bischofberger, J. (2008). Differential dendritic $\mathrm{Ca}^{2+}$ signalling in young and mature hippocampal granule cells. J. Physiol. 586, 3795-3811. doi: 10.1113/jphysiol.2008.155739

Sugiyama, T., Osumi, N., and Katsuyama, Y. (2013). The germinal matrices in the developing dentate gyrus are composed of neuronal progenitors at distinct differentiation stages. Dev. Dyn. 242, 1442-1453. doi: 10.1002/dvdy. 24035

Sun, Y., Hu, J., Zhou, L., Pollard, S. M., and Smith, A. (2011). Interplay between FGF2 and BMP controls the self-renewal, dormancy and differentiation of rat neural stem cells. J. Cell Sci. 124, 1867-1877. doi: 10.1242/jcs.085506

Sun, A. X., Yuan, Q., Tan, S., Xiao, Y., Wang, D., Khoo, A. T., et al. (2016). Direct induction and functional maturation of forebrain GABAergic neurons from human pluripotent stem cells. Cell Rep. 16, 1942-1953. doi: 10.1016/j.celrep. 2016.07.035

Tamminga, C. A., Stan, A. D., and Wagner, A. D. (2010). The hippocampal formation in schizophrenia. Am. J. Psychiatry 167, 1178-1193. doi: 10.1176/appi.ajp.2010.09081187

Temprana, S. G., Mongiat, L. A., Yang, S. M., Trinchero, M. F., Alvarez, D. D., Kropff, E., et al. (2015). Delayed coupling to feedback inhibition during a critical period for the integration of adult-born granule cells. Neuron 85, 116-130. doi: 10.1016/j.neuron.2014.11.023

Theil, T., Alvarez-Bolado, G., Walter, A., and Ruther, U. (1999). Gli3 is required for Emx gene expression during dorsal telencephalon development. Development 126, 3561-3571.

Tole, S., Christian, C., and Grove, E. A. (1997). Early specification and autonomous development of cortical fields in the mouse hippocampus. Development 124, 4959-4970.

Valente, M., Roy, V., Lacy, M. Q., Dispenzieri, A., and Gertz, M. A. (2006). Autologous stem cell transplantation and IgM amyloidosis. Leuk. Lymphoma 47, 1006-1012. doi: 10.1080/10428190600572624

Valvezan, A. J., and Klein, P. S. (2012). GSK-3 and Wnt signaling in neurogenesis and bipolar disorder. Front. Mol. Neurosci. 5:1. doi: 10.3389/fnmol.2012.00001

Vanderhaeghen, P. (2012). Generation of cortical neurons from pluripotent stem cells. Prog. Brain Res. 201, 183-195. doi: 10.1016/B978-0-444-59544-7.00009-3

Villeda, S. A., Luo, J., Mosher, K. I., Zou, B., Britschgi, M., Bieri, G., et al. (2011). The ageing systemic milieu negatively regulates neurogenesis and cognitive function. Nature 477, 90-94. doi: 10.1038/nature10357

Walton, N. M., Zhou, Y., Kogan, J. H., Shin, R., Webster, M., Gross, A. K., et al. (2012). Detection of an immature dentate gyrus feature in human schizophrenia/bipolar patients. Transl. Psychiatry 2:e135. doi: 10.1038/tp. 2012.56 
Wang, S., Scott, B. W., and Wojtowicz, J. M. (2000). Heterogenous properties of dentate granule neurons in the adult rat. J. Neurobiol. 42, 248-257. doi: 10.1002/(sici)1097-4695(20000205)42:2<248::aid-neu8>3.3.co;2-a

Watanabe, K., Kamiya, D., Nishiyama, A., Katayama, T., Nozaki, S., Kawasaki, H., et al. (2005). Directed differentiation of telencephalic precursors from embryonic stem cells. Nat. Neurosci. 8, 288-296. doi: 10.1038/nn1402

Wernig, M., Zhao, J. P., Pruszak, J., Hedlund, E., Fu, D., Soldner, F., et al. (2008). Neurons derived from reprogrammed fibroblasts functionally integrate into the fetal brain and improve symptoms of rats with Parkinson's disease. Proc. Natl. Acad. Sci. U S A 105, 5856-5861. doi: 10.1073/pnas.0801677105

Wilkinson, G., Dennis, D., and Schuurmans, C. (2013). Proneural genes in neocortical development. Neuroscience 253, 256-273. doi: 10.1016/j. neuroscience.2013.08.029

Xu, L., Tang, X., Wang, Y., Xu, H., and Fan, X. (2015). Radial glia, the keystone of the development of the hippocampal dentate gyrus. Mol. Neurobiol. 51, 131-141. doi: 10.1007/s12035-014-8692-y

$\mathrm{Xu}$, C. J., Wang, J. L., and Jin, W. L. (2015). The neural stem cell microenvironment: focusing on axon guidance molecules and myelinassociated factors. J. Mol. Neurosci. 56, 887-897. doi: 10.1007/s12031-0150538-1

Yamasaki, N., Maekawa, M., Kobayashi, K., Kajii, Y., Maeda, J., Soma, M., et al. (2008). $\alpha$-CaMKII deficiency causes immature dentate gyrus, a novel candidate endophenotype of psychiatric disorders. Mol. Brain 1:6. doi: 10.1186/17566606-1-6

Yassa, M. A., Lacy, J. W., Stark, S. M., Albert, M. S., Gallagher, M., and Stark, C. E. (2011). Pattern separation deficits associated with increased hippocampal CA3 and dentate gyrus activity in nondemented older adults. Hippocampus 21, 968-979. doi: 10.1002/hipo.20808

Yoshida, M., Assimacopoulos, S., Jones, K. R., and Grove, E. A. (2006). Massive loss of Cajal-Retzius cells does not disrupt neocortical layer order. Development 133, 537-545. doi: 10.1242/dev.02209

Yu, D. X., Di Giorgio, F. P., Yao, J., Marchetto, M. C., Brennand, K., Wright, R., et al. (2014a). Modeling hippocampal neurogenesis using human pluripotent stem cells. Stem Cell Reports 2, 295-310. doi: 10.1016/j.stemcr.2014. 01.009
Yu, D. X., Marchetto, M. C., and Gage, F. H. (2014b). How to make a hippocampal dentate gyrus granule neuron. Development 141, 2366-2375. doi: 10.1242/dev. 096776

Yuan, F., Fang, K. H., Cao, S. Y., Qu, Z. Y., Li, Q., Krencik, R., et al. (2015). Efficient generation of region-specific forebrain neurons from human pluripotent stem cells under highly defined condition. Sci. Rep. 5:18550. doi: 10.1038/srep 18550

Zhang, C. L., Zou, Y., He, W., Gage, F. H., and Evans, R. M. (2008). A role for adult TLX-positive neural stem cells in learning and behaviour. Nature 451, 1004-1007. doi: 10.1038/nature06562

Zhao, Y., Sheng, H. Z., Amini, R., Grinberg, A., Lee, E., Huang, S., et al. (1999). Control of hippocampal morphogenesis and neuronal differentiation by the LIM homeobox gene Lhx5. Science 284, 1155-1158. doi: 10.1126/science.284. 5417.1155

Zhao, C., Teng, E. M., Summers, R. G. Jr., Ming, G. L., and Gage, F. H. (2006). Distinct morphological stages of dentate granule neuron maturation in the adult mouse hippocampus. J. Neurosci. 26, 3-11. doi: 10.1523/jneurosci.364805.2006

Zhou, C.-J., Zhao, C., and Pleasure, S. J. (2004). Wnt signaling mutants have decreased dentate granule cell production and radial glial scaffolding abnormalities. J. Neurosci. 24, 121-126. doi: 10.1523/jneurosci.4071-03.2004

Zimmer, C., Lee, J., Griveau, A., Arber, S., Pierani, A., Garel, S., et al. (2010). Role of Fgf8 signalling in the specification of rostral Cajal-Retzius cells. Development 137, 293-302. doi: 10.1242/dev.041178

Conflict of Interest Statement: The authors declare that the research was conducted in the absence of any commercial or financial relationships that could be construed as a potential conflict of interest.

Copyright (C) 2018 Hatami, Conrad, Naghsh, Alvarez-Bolado and Skutella. This is an open-access article distributed under the terms of the Creative Commons Attribution License (CC BY). The use, distribution or reproduction in other forums is permitted, provided the original author(s) and the copyright owner(s) are credited and that the original publication in this journal is cited, in accordance with accepted academic practice. No use, distribution or reproduction is permitted which does not comply with these terms. 